\title{
Artificial Maturation of Iron- and Sulfur-Rich Mars Analogues: Implications for the Diagenetic Stability of Biopolymers and Their Detection with Pyrolysis-Gas Chromatography-Mass Spectrometry
}

\author{
Jonathan S.W. Tan, Samuel H. Royle, and Mark A. Sephton
}

\begin{abstract}
Acidic iron- and sulfur-rich streams are appropriate analogues for the late Noachian and early Hesperian periods of martian history, when Mars exhibited extensive habitable environments. Any past life on Mars may have left behind diagnostic evidence of life that could be detected at the present day. For effective preservation, these remains must have avoided the harsh radiation flux at the martian surface, survived geological storage for billions of years, and remained detectable within their geochemical environment by analytical instrument suites used on Mars today, such as thermal extraction techniques.

We investigated the detectability of organic matter within sulfur stream sediments that had been subjected to artificial maturation by hydrous pyrolysis. After maturation, the samples were analyzed by pyrolysis-gas chromatography-mass spectrometry (py-GC-MS) to determine whether organic matter could be detected with this commonly used technique. We find that macromolecular organic matter can survive the artificial maturation process in the presence of iron- and sulfur-rich minerals but cannot be unambiguously distinguished from abiotic organic matter. However, if jarosite and goethite are present in the sulfur stream environment, they interfere with the py-GC-MS detection of organic compounds in these samples. Clay reduces the obfuscating effect of the oxidizing minerals by providing nondeleterious adsorption sites. We also find that after a simple alkali and acid leaching process that removes oxidizing minerals such as iron sulfates, oxides, and oxyhydroxides, the sulfur stream samples exhibit much greater organic responses during py-GC-MS in terms of both abundance and diversity of organic compounds, such as the detection of hopanes in all leached samples.

Our results suggest that insoluble organic matter can be preserved over billions of years of geological storage while still retaining diagnostic organic information, but sample selection strategies must either avoid jarositeand goethite-rich outcrops or conduct preparative chemistry steps to remove these oxidants prior to analysis by thermal extraction techniques. Key Words: Mars-Biosignature-Hydrous pyrolysis-py-GC-MS—Artificial maturation-Alkali/Acid leaching. Astrobiology 21, 199-218.
\end{abstract}

\section{Introduction}

$\mathbf{T}$ HE SEARCH FOR extinct and extant life on Mars has been an ongoing goal of the astrobiological community (e.g., Des Marais et al., 2008; Mustard et al., 2013; Beegle et al., 2015; Horneck et al., 2016). The reliability of attempts to detect and identify biosignatures in the martian rock record is dependent on appropriate sample selection strategies. The investigation of terrestrial analogues is useful to fully understand how biosignatures are produced, preserved, degraded, and potentially detected in martian sediments.
Martian geological history is characterized by sweeping transitional changes in the surface conditions of the planet, which in turn had strong influences over minerals deposited during these time periods (Bibring et al., 2006; Ehlmann et al., 2011; Gaillard et al., 2013). The late Noachian and early Hesperian periods of martian history represent a temporal window during which conditions were most habitable, and when any possible martian life may have had the opportunity to develop (Cockell, 2014; Westall et al., 2015). Increased volcanic activity during this period led to the injection of large volumes of $\mathrm{SO}_{2}$ into the martian atmosphere

Impacts and Astromaterials Research Centre, Department of Earth Science and Engineering, Imperial College London, London, UK.

(c) Jonathan S.W. Tan et al., 2020; Published by Mary Ann Liebert, Inc. This Open Access article is distributed under the terms of the Creative Commons Attribution Noncommercial License (http://creativecommons.org/licenses/by-nc/4.0/) which permits any noncommercial use, distribution, and reproduction in any medium, provided the original author(s) and the source are credited. 
(Gaillard et al., 2013). This encouraged the deposition of sedimentary sulfate minerals such as gypsum $\left(\mathrm{CaSO}_{4} \cdot 2 \mathrm{H}_{2} \mathrm{O}\right)$, jarosite $\left(\mathrm{KFe}_{3}^{3+}(\mathrm{OH})_{6}\left(\mathrm{SO}_{4}\right)_{2}\right)$, and kieserite $\left(\mathrm{MgSO}_{4} \cdot \mathrm{H}_{2} \mathrm{O}\right)$, as well as iron oxides and oxyhydroxides such as hematite $\left(\mathrm{Fe}_{2} \mathrm{O}_{3}\right)$ and goethite $(\mathrm{FeOOH})$ (Klingelhöfer et al., 2004; Squyres et al., 2004; Gendrin et al., 2005; Bibring et al., 2006; Milliken et al., 2010; Gaillard et al., 2013).

Sulfur stream environments are found to be appropriate terrestrial analogues for Hesperian Mars (Burns, 1987; Fernández-Remolar et al., 2005; Amils et al., 2007; Kaplan et al., 2016). These environments arise as a result of the oxidation of sulfide-containing minerals, due to their exposure to air, water, or specific microbial communities. Aqueous sulfates produced by this process are transported via groundwater, emerge in acidic sulfur streams, and are precipitated as sulfate salts such as jarosite (Bigham and Nordstrom, 2000; Papike et al., 2006). Understanding how mineral assemblages found in these terrestrial environments affect the preservation and/or detection of fossilized biosignatures can aid current and future habitability and lifedetection missions to Mars. If these environments also hosted life on Mars, then evidence may remain preserved in the rock record, either by the entombment of organic remains within minerals (Ferris et al., 1989; Fernández-Remolar and Knoll, 2008; François et al., 2016), the encrustation of biological material (Fernández-Remolar et al., 2005; Parenteau and Cady, 2010; Preston et al., 2011), or the association of organic biomolecules with iron phases (Lalonde et al., 2012; Williams et al., 2016; Tan et al., 2018). On Earth, analogous environments are capable of supporting communities of extremophilic organisms (Fernández-Remolar et al., 2005; Benison and Bowen, 2006; Williams et al., 2015).

Biological lipids are core components of cellular membranes that make for excellent biosignatures due to being diagnostic of biological and metabolic processes (Vestal and White, 1989; White, 1993; Volkman et al., 1998) and resistant to degradation (Brocks et al., 1999; Brocks and Summons, 2004; Killops and Killops, 2005; Peters et al., 2005). Previous studies have shown that lipid biosignatures can be concentrated in iron-rich phases in sulfur stream environments (Tan et al., 2018) and that they may be detected by analytical techniques conducted by instrument suites on current missions to Mars (Colín-García et al., 2011; Preston et al., 2011; Williams et al., 2019). Furthermore, biogenic patterns within lipid profiles, specifically even-over-odd predominance patterns in carbon-chain lengths of monocarboxylic acids, are also preserved past the initial stages of diagenesis (Tan et al., 2018).

Sample selection strategies must consider the effects of long-term, postburial diagenesis. For fossilized biosignatures from the late Noachian and early Hesperian to be detected at the present day, they must have survived for at least 3.6-3.8 Ga. During this time, the degradative effects of high-energy and cosmic radiation would have rendered any organic matter present in the near surface indistinguishable from abiotic carbon (Brocks and Summons, 2004; Dartnell, 2011; Pavlov et al., 2012; Hassler et al., 2014). However, even relatively shallow burial has been shown to result in a significant increase in the preservation of organic material (Kminek and Bada, 2006; Pavlov et al., 2012).

Burial on Mars is a rare event relative to environments on Earth owing to the lack of plate tectonics on the Red Planet, but can occur during continuous sedimentation and compaction. An example of this burial regime can be found in Gale Crater, where sediments at Yellowknife Bay were observed to have been buried and subsequently exhumed between 3.3 and 3.2 Ga (Edgett et al., 2016; Caswell and Milliken, 2017). Hydraulic analysis of these sediments revealed a minimum burial depth of $1.2 \mathrm{~km}$ and exposure to temperatures between $80^{\circ} \mathrm{C}$ and $225^{\circ} \mathrm{C}$, depending on factors such as geothermal gradient and thermal conductivity, among others (Hoffman, 2001; Borlina et al., 2015). Consequently, sample selection strategies must consider the effects of long-term, postburial diagenesis, including relatively elevated temperatures and pressures, and any reactions involving the interaction of fluids, organic matter, and the mineral matrix.

In sedimentary rocks on Earth, burial and subsequent diagenesis of biologically derived organic matter result in condensation and polymerization to form insoluble macromolecular compounds termed kerogen. Kerogen formation has been extensively studied, and there are several models that have been suggested to describe this complex process, including the neogenesis model (Tissot and Welte, 1984) and the selective preservation model (Tegelaar et al., 1989). Other mechanisms include natural vulcanization (Sinninghe Damste et al., 1989; Sinninghe Damste and De Leeuw, 1990) and oxidative polymerization (Versteegh et al., 2004). Mars has a significantly different geological context than that of Earth, and the extent to which terrestrial kerogenforming mechanisms can be applied to martian sedimentary environments is uncertain. Recent identification of sulfurcontaining compounds on Mars (Eigenbrode et al., 2018) suggests that at least some of these processes (e.g., natural vulcanization) may be occurring on Mars.

Hydrous pyrolysis is an artificial maturation technique by which the early to late stages of diagenesis can be simulated by subjecting samples to high temperatures (e.g., between $200^{\circ} \mathrm{C}$ and $280^{\circ} \mathrm{C}$ ) in the presence of deoxygenated water and an inert atmosphere in a closed system (e.g., Lewan, 1985). Hydrous pyrolysis has traditionally been used to determine the effects of thermal maturation on biomarkers contained within organic-rich rocks (Lewan, 1985; Eglinton and Douglas, 1988; Peters et al., 1990; Koopmans et al., 1996; Jaeschke et al., 2008; Mißbach et al., 2016). This technique has increasingly been applied to terrestrially sourced Mars-analogue samples to investigate the effects of diagenesis on potential martian biosignatures (Royle et al., 2018b; Tan and Sephton, 2019).

Recent work has already shown that it is unlikely for solvent-extractable organic matter to be preserved past the late stages of postburial diagenesis under iron-rich conditions (Tan and Sephton, 2019); other accessing approaches for information preserved in fossilized organic material must be investigated. Thermal extraction experiments have historically been the analytical technique used in missions to Mars, having been used with gas chromatograph-mass spectrometers (GC-MS) on the Viking landers (Anderson et al., 1972; Biemann et al., 1977), the Thermal and Evolved Gas Analyzer (TEGA) on the Phoenix mission (Guinn et al., 2008; Hecht et al., 2009; Kounaves et al., 2009; Ming et al., 2009), and the Sample Analysis at Mars (SAM) instrument on the Mars Science Laboratory (MSL) Curiosity rover (Grotzinger et al., 2012; Mahaffy et al., 2012). Future 
missions such as the Mars Organic Molecule Analyzer (MOMA) instrument on the ExoMars mission will also use thermal extraction techniques (Brinckerhoff et al., 2013; Goetz et al., 2016; Goesmann et al., 2017).

The presence of oxidizing minerals on the surface of Mars, however, complicates the use of thermal extraction techniques. Perchlorates (Hecht et al., 2009) and sulfates (Lewis et al., 2015) are known to thermally decompose to release significant amounts of oxygen that reacts with organic matter and prevents its detection, but iron oxide and oxyhydroxides from sulfur stream environments have been found to be slightly more amenable to thermal extraction techniques (Lewis et al., 2018). While oxidizing minerals reduce the response for organic matter during thermal extraction, different minerals degrade them to different extents; the detectability of organic matter in a specific sample would depend on organic matter-mineral ratios (Royle et al., 2018a). The problem of oxidizing minerals has resulted in several studies aimed at mitigating the thermal extraction problem, either in the form of exploring alternative organic matter extraction techniques (Mahaffy et al., 2012; Brinckerhoff et al., 2013; Beegle et al., 2015), in situ derivatization (Mißbach et al., 2019), or in the form of sample handling and processing, such as utilizing stepped heating and recording the temperature of release of oxidized carbon (Sephton et al., 2014), and the aqueous leaching of samples to remove soluble oxidizing salts (e.g., perchlorate) (Montgomery et al., 2019).

In this study, we report on the pyrolysis-gas chromatographymass spectrometry (py-GC-MS) analysis of two mineralogically distinct acidic sulfur stream samples that were artificially matured prior to analysis. The goal of this investigation was to determine whether biosignatures could survive long-term postburial diagenesis and whether any remaining biological signals could be detected with techniques analogous to thermal extraction methods used in current and future missions to Mars. In addition, we investigated the use of alkali and acid leaching as a means to mitigate the obfuscating properties of jarosite, hematite, and goethite present in these samples.

\section{Materials and Methods}

\subsection{Sample description}

Samples were collected from two acidic, iron- and sulfurrich streams located in Dorset, United Kingdom, in preparation for the experimental workflow used in this study (Fig. 1). These samples were first collected and mineralogically assessed by using X-ray diffraction (XRD) in October 2012, and a second round of sample collection was conducted in October 2017. A more in-depth description of the geology and mineralogy of the sulfur stream samples can be found in the literature (Lewis et al., 2018; Tan et al., 2018). In brief, these sulfur stream samples were primarily comprised of quartz, jarosite, and goethite (Lewis et al., 2018; Tan et al., 2018). The distribution of mineral abundances in the study area varied with water availability; jarosite was observed in dry areas, while goethite was observed in areas that were more persistently waterlogged (Lewis et al., 2018; Tan et al., 2018).

The first set of sulfur stream samples was collected from St. Oswald's Bay, Dorset. The acidic stream ( $\mathrm{pH} 3$ ) was observed to host an extremophilic sulfur-centric mi- crobial ecosystem composed of acidophilic algae, and microbial mats of phototrophic purple sulfur bacteria (Tan et al., 2018). Additional organic inputs into the system included charcoal wood fragments eroded from the nearby stratigraphy, as well as terrestrial plant matter (Tan et al., 2018).

The second set of sulfur stream samples was collected from Stair Hole, Dorset. This slightly less acidic stream ( $\mathrm{pH} \mathrm{5)}$ possessed a slightly weaker flow rate and a thinner microbial mat than observed at St. Oswald's Bay. Prior XRD analysis of the Stair Hole samples revealed a slightly more clay-rich component (up to $36 \%$ of bulk rock) than found at St. Oswald's Bay, composed of kaolinite and illite (Lewis et al., 2018).

Extracted cores were packaged in aluminum foil and returned to the laboratory where they were immediately freeze-dried in a Labconco freeze dryer. Individual layers within each core were separated with a saw (cleaned with methanol and dichloromethane [DCM]). Subsamples were subsequently ground and homogenized with a ceramic pestle and mortar.

Of the samples collected, FlowMG1a and DryMJ1a (from the naming convention used in Tan et al., 2018) were chosen for this study. FlowMG1a was gathered from St. Oswald's Bay and is hereafter referred to as the clay-poor stream sample, while DryMJ1a was gathered from Stair Hole and is hereafter referred to as the clay-rich stream sample. The two samples were selected as being potentially representative of the acidic iron- and sulfur-rich deposits found during Hesperian Mars, containing soils with high goethite and minor jarosite content, microbial mat material, and in the case of the clay-rich stream sample, clay minerals including illite and kaolinite.

\subsection{Hydrous pyrolysis and solvent extraction}

The artificial maturation of the samples followed the hydrous pyrolysis setup described in Tan and Sephton (2019). The amount of water added to each reaction bomblet varied depending on the water-to-rock ratios to be tested, with $0.1 \mathrm{~mL}$ deionized (DI) water added to "low" water-torock ratio samples and $0.5 \mathrm{~mL}$ DI water added to "high" water-to-rock ratio samples. Hydrous pyrolysis was performed on samples at $200^{\circ} \mathrm{C}, 240^{\circ} \mathrm{C}$, and $280^{\circ} \mathrm{C}$ for $72 \mathrm{~h}$ (Table 1).

Solvents were extracted following the procedure detailed in Tan and Sephton (2019). The solid residue was then ultrasonically extracted by methanol $(3 \times)$, DCM:methanol $(1 / 1, v / v)(3 \times)$, and DCM $(3 \times)$. Solvent extraction was conducted to ensure that all organic material detected during py-GC-MS was derived from insoluble macromolecular material. Following the removal of solvent-extractable organic matter, the residues were air-dried and stored until analysis.

\subsection{Alkali and acid treatment}

As a means to remove iron sulfate and iron (oxy)hydroxide minerals that have been shown to interfere with organic matter detection during py-GC-MS analysis (Lewis et al., 2018), half of the remaining hydrous pyrolysis residue was treated with a strong alkali, followed by a strong acid.

Samples were placed into centrifuge tubes for alkali/ acid treatment. In each case, the samples were agitated 


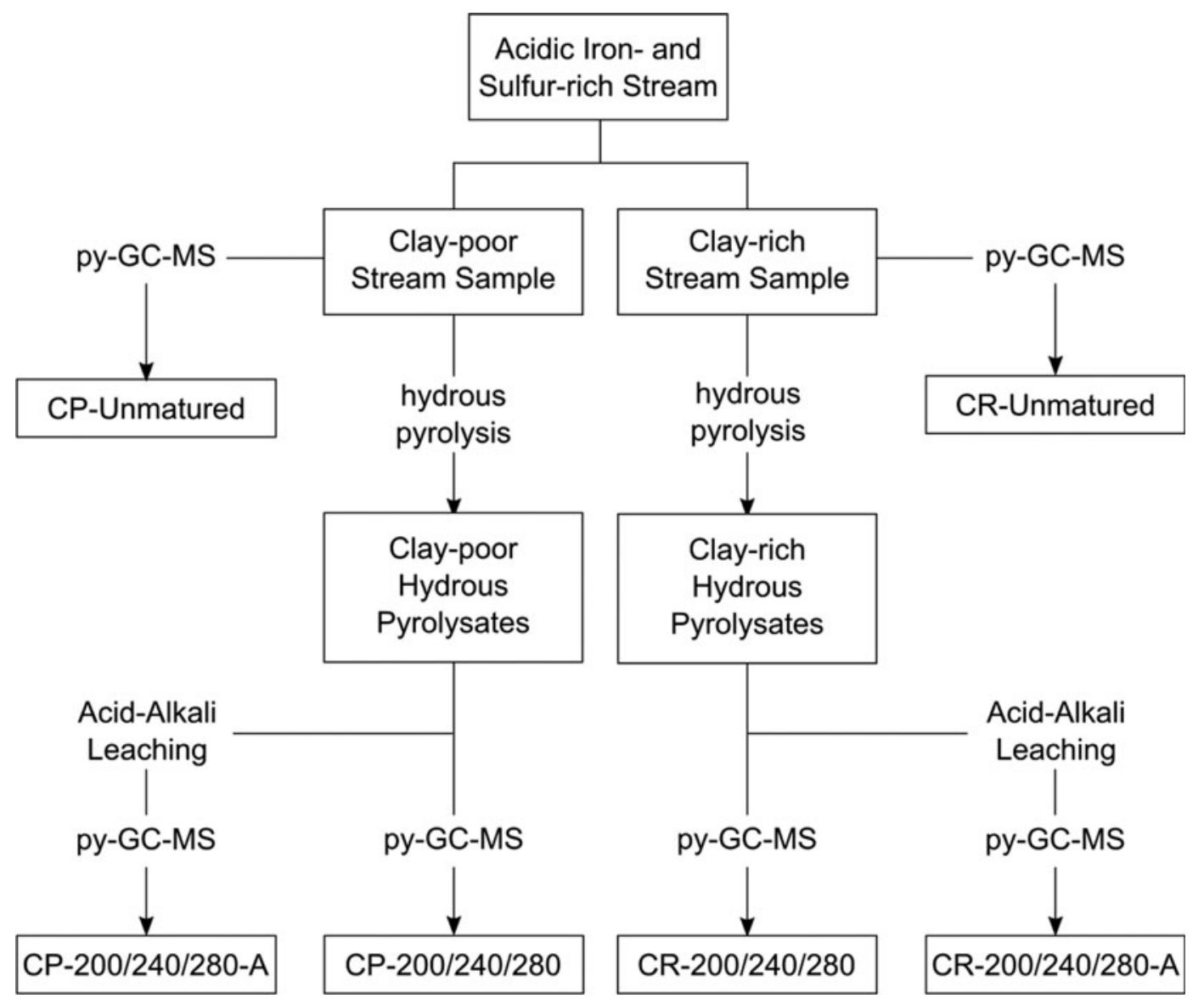

FIG. 1. Diagrammatic description of the experimental workflow used in this study. The types of fractions are referred to as the following: Untreated clay-poor pyrolysate $=\mathrm{CP}$, no suffix; untreated clay-rich pyrolysate $=\mathrm{CR}$, no suffix; treated claypoor pyrolysate $=\mathrm{CP}$, "A" suffix; treated clay-rich pyrolysate $=\mathrm{CR}$, "A" suffix.

sonically for $5 \mathrm{~min}$ after the addition of alkali/acid. The samples were first treated with an excess of $1 \mathrm{M} \mathrm{NaOH}$ solution to remove jarosite from the samples. The samples were left for $24 \mathrm{~h}$ before washing. Subsequently, the samples were treated with an excess of $4 \mathrm{M} \mathrm{HCl}$ for $24 \mathrm{~h}$ to remove any iron oxides from the sample (Sidhu et al., 1981). The acid treatment was repeated for 4 days to ensure that as much iron oxide was removed from the samples as possible.

Once treated, the samples were washed by adding DI water, centrifuging and decanting the supernatant until it was no longer acidic ( $\mathrm{pH} 7)$. In addition, a total dissolved solids (TDS) probe was used to ensure that no salts produced by the alkali/acid treatment remained in the sample (conductivity $<20 \mu \mathrm{S} / \mathrm{cm}$ ). The samples were then air-dried in preparation for py-GC-MS analysis.

\subsection{Pyrolysis-gas chromatography-mass spectrometry}

The py-GC-MS analysis followed the setup described in the work of Royle et al. (2018a). Five to ten milligrams of each sample (Table 1) was loaded into quartz pyrolysis tubes and secured at both ends with clean quartz wool (furnaced overnight at $450^{\circ} \mathrm{C}$ ). Each pyrolysis tube was inserted into the platinum coil of a Chemical Data Systems Analytical 2000
Pyroprobe in a helium atmosphere and heated with a ramp rate of $20^{\circ} \mathrm{C} \mathrm{ms}^{-1}$ to $650^{\circ} \mathrm{C}$ and held for $15 \mathrm{~s}$.

Separation and identification of the pyrolysis products was conducted by GC-MS by using an Agilent Technologies 6890 gas chromatograph (GC) coupled to an Agilent Technologies 5973 mass spectrometer (MS). The interface was held at $270^{\circ} \mathrm{C}$ with a split ratio of $10: 1$. Separation was performed by an SGE BPX5 column $(25 \mathrm{~m} \times 220 \mu \mathrm{m} \times$ $0.25 \mu \mathrm{m}$ ), with helium as a carrier gas at a constant column flow of $11 \mathrm{~mL} \mathrm{~min}^{-1}$. The GC oven was held at $40^{\circ} \mathrm{C}$ for $2 \mathrm{~min}$, then heated at a rate of $5^{\circ} \mathrm{C} \mathrm{min}-1$ to $310^{\circ} \mathrm{C}$ and held for $10 \mathrm{~min}$. Mass spectra were acquired in the scan range of 45-550 amu. Peak identification was based on retention order and mass spectra comparisons with authenticated standards and by reference to the NIST-08 mass spectral database.

Data from the laboratory pyrolysis-GC-MS is assumed to be comparable to that from the SAM and MOMA experimental setups. Differences between laboratory- and rover-based instruments could affect the distribution of pyrolysis products (Moldoveanu, 2010a), particularly heating rate at $20^{\circ} \mathrm{C} \mathrm{ms}^{-1}$ for laboratory pyrolysis compared to $35^{\circ} \mathrm{C}$ or $200^{\circ} \mathrm{C} \mathrm{min}{ }^{-1}$ for SAM and MOMA, respectively (Mahaffy et al., 2012; Goesmann et al., 2017). A full comparison between laboratory and rover-based pyrolysis parameters can be found in the work of Lewis et al. (2018). In addition, flash pyrolysis can be 
Table 1. Samples, Sample Codes, and Conditions Chosen for Hydrous Pyrolysis Experiments

\begin{tabular}{|c|c|c|c|c|c|}
\hline Sample code & Locality & $\begin{array}{c}\text { Water } \\
\text { added }(m L)\end{array}$ & $\begin{array}{c}\text { Hydrous pyrolysis } \\
\text { temp. }\left({ }^{\circ} \mathrm{C}\right)\end{array}$ & $\begin{array}{l}\text { Alkali and } \\
\text { acid treated }\end{array}$ & $X R D$ data \\
\hline \multicolumn{6}{|l|}{ Clay-poor stream } \\
\hline CP-Unmatured & St. Oswald's Bay & N/A & N/A & No & Q:64, G:26, J:10, I:0, K:0, M:0 \\
\hline CP-Unmatured-A & St. Oswald's Bay & N/A & N/A & Yes & Same as CP-Unmatured \\
\hline CP-200 & St. Oswald's Bay & 0.1 & 200 & No & Same as CP-Unmatured \\
\hline CP-240 & St. Oswald's Bay & 0.1 & 240 & No & Same as CP-Unmatured \\
\hline CP-280 & St. Oswald's Bay & 0.1 & 280 & No & Same as CP-Unmatured \\
\hline CP-200-A & St. Oswald's Bay & 0.1 & 200 & Yes & Same as CP-Unmatured \\
\hline CP-240-A & St. Oswald's Bay & 0.1 & 240 & Yes & Same as CP-Unmatured \\
\hline CP-280-A & St. Oswald's Bay & 0.1 & 280 & Yes & Same as CP-Unmatured \\
\hline \multicolumn{6}{|l|}{ Clav-rich stream } \\
\hline $\begin{array}{l}\text { CR-Unmatured } \\
\text { CR-Unmatured-A }\end{array}$ & $\begin{array}{l}\text { Stair Hole } \\
\text { Stair Hole }\end{array}$ & $\begin{array}{l}\text { N/A } \\
\text { N/A }\end{array}$ & $\begin{array}{l}\text { N/A } \\
\text { N/A }\end{array}$ & $\begin{array}{l}\text { No } \\
\text { Yes }\end{array}$ & $\begin{array}{l}\text { Q:40, G:18, J:6, I:25, K:11, M:0 } \\
\text { Same as CR-Unmatured }\end{array}$ \\
\hline CR-200 & Stair Hole & 0.1 & 200 & No & Same as CR-Unmatured \\
\hline CR-240 & Stair Hole & 0.1 & 240 & No & Same as CR-Unmatured \\
\hline CR-280 & Stair Hole & 0.1 & 280 & No & Same as CR-Unmatured \\
\hline CR-200-A & Stair Hole & 0.1 & 200 & Yes & Same as CR-Unmatured \\
\hline CR-240-A & Stair Hole & 0.1 & 240 & Yes & Same as CR-Unmatured \\
\hline CR-280-A & Stair Hole & 0.1 & 280 & Yes & Same as CR-Unmatured \\
\hline
\end{tabular}

All samples were hydrously pyrolyzed for $72 \mathrm{~h}$. XRD data collection and analysis taken from Lewis et al. (2018). Q=quartz; $\mathrm{G}=$ goethite; $\mathrm{J}=$ jarosite; $\mathrm{I}=$ illite; $\mathrm{K}=$ kaolinite; $\mathrm{M}=$ montmorillonite.

advantageous in a laboratory analogue experiment as it may provide a "worst-case scenario" ensuring the coincident reactions of both the inorganic and organic phases, which can be minimized during ramped pyrolysis (Lewis et al., 2018; Royle et al., 2018a). The setup for the GC ovens on both SAM and MOMA is comparable to our laboratory experiment, and detected compounds were similarly identified by reference to a NIST spectral library (Glavin et al., 2013).

\section{Results}

In this section, we present the py-GC-MS products of hydrously pyrolyzed acid stream samples. The data is presented diagrammatically as annotations on chromatograms, and a summary of the compounds that were identified in each sample is described in Table 2. We used the prefix CP to refer to samples from the clay-poor stream and the prefix CR to refer to samples from the clay-rich stream.

Control samples were produced by using quartz sand that was hydrously pyrolyzed at $240^{\circ} \mathrm{C}$ for $72 \mathrm{~h}$ then flash pyrolyzed using the parameters described in Section 2.4 (Supplementary Fig. S1). When the experimental residues were analyzed, no py-GC-MS products were detected (except siloxanes, which are attributed to column bleed). Following the analysis of all samples, it was found that varying water-to-rock ratios during hydrous pyrolysis had little to no effect on the final py-GC-MS products (Supplementary Figs. S2 and S3). As such, only the chromatograms of the samples using low water-to-rock ratios are presented in this manuscript.

\subsection{Clay-poor sulfur stream sample-no alkali/acid treatment}

There were significant differences between the chromatograms of the unmatured core samples (CP-Unmatured) and the samples that had been subjected to hydrous pyrolysis (CP-200,
CP-240, CP-280), primarily in the diversity and abundance of organic compounds (Fig. 2). In all samples, a single dominant low mass peak was present. In samples that were subjected to hydrous pyrolysis, this low mass peak dominated the chromatogram and necessitated scaling the chromatogram such that the few identifiable peaks - composed of benzene and thiophene responses - could be observed. Previous py-GC-MS studies at low amu scan ranges have shown that low mass peaks produced during the pyrolysis of natural jarosite-rich sediments contain $\mathrm{SO}_{2}, \mathrm{CO}_{2}$, and $\mathrm{H}_{2} \mathrm{O}$, with minor $\mathrm{CO}$ (Lewis et al., 2015).

In the unmatured sample, significant amounts of pyrolysis products indicative of biological materials were observed. Compounds detected were primarily aromatic, including benzenes, pyridine, styrene, indenes, indoles, benzonitriles, (benzo)furans, (benzo)thiophenes, and thiophene-carbonitriles.

While the py-GC-MS signal was dominated by a large low mass peak, the hydrously pyrolyzed samples (CP-200, CP240, and CP-280) produced aromatic organic compounds such as methyl-, dimethyl- and trimethyl-benzenes, styrene, and benzonitriles, in addition to simple heterocyclic aromatics such as (benzo)thiophenes and (benzo)furans. The largest organic compound observed was naphthalene, and only at abundances very close to the limits of detection. The low organic response in these samples is consistent with the loss of organic material during simulated diagenesis, with decreasing organic responses correlated with increasing hydrous pyrolysis temperatures (Tan and Sephton, 2019). This is best expressed in the decrease in abundance of benzonitrile, as well as the loss of benzofuran in sample CP-280.

\subsection{Clay-rich sulfur stream sample-no alkali/acid treatment}

Like the chromatograms of the clay-poor samples, CRUnmatured produced a much greater organic response than any 
Table 2. Organic Compounds Observed in Each of the Pyrolyzed Sulfur Stream Samples

\begin{tabular}{|c|c|c|c|c|c|c|c|c|c|c|c|c|c|c|c|c|}
\hline \multirow[b]{4}{*}{ Organic compound } & \multicolumn{16}{|c|}{ Sample name } \\
\hline & \multicolumn{8}{|c|}{ No alkali/acid treatment } & \multicolumn{8}{|c|}{ Alkali/Acid treated } \\
\hline & \multicolumn{4}{|c|}{$\begin{array}{c}\text { Clay-poor sulfur } \\
\text { stream }\end{array}$} & \multicolumn{4}{|c|}{$\begin{array}{c}\text { Clay-rich sulfur } \\
\text { stream }\end{array}$} & \multicolumn{4}{|c|}{$\begin{array}{c}\text { Clay-poor sulfur } \\
\text { stream }\end{array}$} & \multicolumn{4}{|c|}{$\begin{array}{c}\text { Clay-rich sulfur } \\
\text { stream }\end{array}$} \\
\hline & 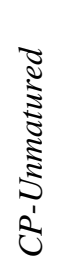 & $\begin{array}{l}\stackrel{8}{8} \\
\stackrel{1}{0}\end{array}$ & 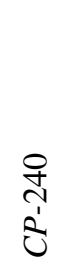 & 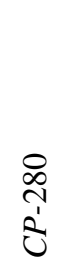 & 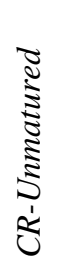 & $\begin{array}{l}\stackrel{\overbrace{}}{1} \\
\stackrel{1}{\cup}\end{array}$ & 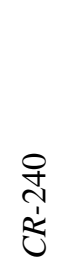 & $\begin{array}{l}\stackrel{\infty}{\infty} \\
\stackrel{1}{\sim} \\
\stackrel{\sim}{U}\end{array}$ & 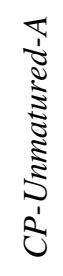 & $\begin{array}{l}\pi \\
\stackrel{1}{8} \\
\stackrel{T}{1} \\
\delta^{\prime}\end{array}$ & $\begin{array}{l}\underset{T}{1} \\
\stackrel{+}{+} \\
\stackrel{1}{0}\end{array}$ & $\begin{array}{l}\mathbb{1} \\
\stackrel{1}{0} \\
\stackrel{1}{1} \\
\stackrel{1}{U}\end{array}$ & 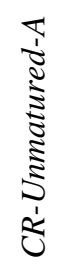 & 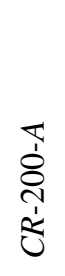 & $\begin{array}{l}\mathbb{1} \\
\stackrel{+}{+} \\
\stackrel{1}{d}\end{array}$ & 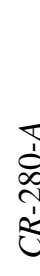 \\
\hline Benzenes & $\checkmark$ & $\checkmark$ & $\checkmark$ & $\checkmark$ & $\checkmark$ & $\checkmark$ & $\checkmark$ & $\checkmark$ & $\checkmark$ & $\checkmark$ & $\checkmark$ & $\checkmark$ & $\checkmark$ & $\checkmark$ & $\checkmark$ & $\checkmark$ \\
\hline Alkyl-benzenes & $\checkmark$ & $\checkmark$ & $\checkmark$ & $\checkmark$ & $\checkmark$ & $\checkmark$ & $\checkmark$ & $\checkmark$ & $\checkmark$ & $\checkmark$ & $\checkmark$ & $\checkmark$ & $\checkmark$ & $\checkmark$ & $\checkmark$ & $\checkmark$ \\
\hline Naphthalenes & $\checkmark$ & $\checkmark$ & $\checkmark$ & $\checkmark$ & $\checkmark$ & $\checkmark$ & $\checkmark$ & & $\checkmark$ & $\checkmark$ & $\checkmark$ & $\checkmark$ & $\checkmark$ & $\checkmark$ & $\checkmark$ & $\checkmark$ \\
\hline Indenes & & & & & & $\checkmark$ & & & $\checkmark$ & $\checkmark$ & $\checkmark$ & $\checkmark$ & $\checkmark$ & $\checkmark$ & $\checkmark$ & $\checkmark$ \\
\hline Polyaromatic hydrocarbons & $\checkmark$ & & & & $\checkmark$ & $\checkmark$ & & & $\checkmark$ & $\checkmark$ & $\checkmark$ & $\checkmark$ & $\checkmark$ & $\checkmark$ & $\checkmark$ & $\checkmark$ \\
\hline Pyridines & $\checkmark$ & & & & $\checkmark$ & $\checkmark$ & $\checkmark$ & $\checkmark$ & $\checkmark$ & $\checkmark$ & $\checkmark$ & $\checkmark$ & $\checkmark$ & $\checkmark$ & $\checkmark$ & $\checkmark$ \\
\hline Indoles & & & & & $\checkmark$ & & & & $\checkmark$ & $\checkmark$ & $\checkmark$ & & $\checkmark$ & $\checkmark$ & $\checkmark$ & $\checkmark$ \\
\hline (Benzo)nitriles & $\checkmark$ & $\checkmark$ & $\checkmark$ & $\checkmark$ & $\checkmark$ & $\checkmark$ & $\checkmark$ & $\checkmark$ & $\checkmark$ & & & & $\checkmark$ & & & \\
\hline Alkylnitriles & & & & & $\checkmark$ & & & & & & & & $\checkmark$ & $\checkmark$ & $\checkmark$ & $\checkmark$ \\
\hline (Benzo)furans & & $\checkmark$ & $\checkmark$ & $\checkmark$ & $\checkmark$ & $\checkmark$ & $\checkmark$ & $\checkmark$ & $\checkmark$ & $\checkmark$ & $\checkmark$ & $\checkmark$ & $\checkmark$ & $\checkmark$ & $\checkmark$ & $\checkmark$ \\
\hline Furfural & $\checkmark$ & & & & $\checkmark$ & & & & $\checkmark$ & & & & $\checkmark$ & & & \\
\hline Ketones & $\checkmark$ & $\checkmark$ & $\checkmark$ & & $\checkmark$ & $\checkmark$ & $\checkmark$ & & $\checkmark$ & $\checkmark$ & $\checkmark$ & $\checkmark$ & $\checkmark$ & $\checkmark$ & $\checkmark$ & $\checkmark$ \\
\hline Indenone & & & & & $\checkmark$ & & & & $\checkmark$ & $\checkmark$ & $\checkmark$ & $\checkmark$ & $\checkmark$ & $\checkmark$ & $\checkmark$ & $\checkmark$ \\
\hline Phenols & & & & & $\checkmark$ & $\checkmark$ & $\checkmark$ & & $\checkmark$ & $\checkmark$ & $\checkmark$ & $\checkmark$ & $\checkmark$ & $\checkmark$ & $\checkmark$ & $\checkmark$ \\
\hline Thiophenes & $\checkmark$ & $\checkmark$ & $\checkmark$ & $\checkmark$ & $\checkmark$ & $\checkmark$ & $\checkmark$ & $\checkmark$ & & & & & & $\checkmark$ & $\checkmark$ & $\checkmark$ \\
\hline Benzothiophene & $\checkmark$ & $\checkmark$ & $\checkmark$ & & $\checkmark$ & $\checkmark$ & $\checkmark$ & $\checkmark$ & & & & & & & & \\
\hline Alkene/Alkane pairs & & & & & & & & & $\checkmark$ & $\checkmark$ & $\checkmark$ & $\checkmark$ & & $\checkmark$ & $\checkmark$ & $\checkmark$ \\
\hline Fatty acids & & & & & $\checkmark$ & & & & $\checkmark$ & $\checkmark$ & & & $\checkmark$ & $\checkmark$ & $\checkmark$ & $\checkmark$ \\
\hline Hopanes & & & & & $\checkmark$ & & & & $\checkmark$ & $\checkmark$ & $\checkmark$ & $\checkmark$ & & $\checkmark$ & $\checkmark$ & $\checkmark$ \\
\hline
\end{tabular}

of the samples that were subjected to hydrous pyrolysis (Fig. 3). Compounds detected in CR-Unmatured are similar to those observed in the clay-poor samples but also include additional compound classes such as phenols. Unlike the clay-poor samples, the clay-rich samples also produce much higher molecular weight compounds, including high molecular weight polyaromatic hydrocarbons (PAHs) like phenanthrene and fluoranthene, heterocyclic aromatic compounds such as fluorenone and dibenzothiophene, and long-chain aliphatics such $\mathrm{C}_{16}$ and $\mathrm{C}_{18}$ fatty acids, hexadecanenitrile, and 3-(4,8,12trimethyltridecyl)thiophene. These organic compounds are consistent with the py-GC-MS products of sulfur stream samples that contained relatively low jarosite contents and hence less interference from evolved $\mathrm{O}_{2}$ (Lewis et al., 2018). Like CPUnmatured, valine was also observed in exclusively the CRUnmatured sample. Several species of hopanes were also detected in the py-GC-MS products of CR-Unmatured but were absent in any of the samples that had been subjected to hydrous pyrolysis. While hopanes were not observed in previous flash pyrolysis studies conducted in this area (Lewis et al., 2018), their presence in the sample was not unexpected due to their ubiquity in bacterial cell membranes (e.g., Peters et al., 2005).

The organic responses of the clay-rich samples that were subjected to hydrous pyrolysis (CR-200, CR-240, CR-280) were found to be consistent with the loss of organic matter during simulated diagenesis. As hydrous pyrolysis temperatures increased, the organic response of the samples de- creased, in terms of the abundance of organic compounds but also in the maximum molecular weight observed in the sample. While high molecular weight compounds such as phenanthrene were observed in CR-200, the largest organic compound observed in CR-280 was naphthalene.

Several key differences were observed between the claypoor sulfur stream samples (Section 3.1) and these clay-rich sulfur stream samples. In general, organic responses were observed to be higher in the clay-rich samples compared to the clay-poor samples, especially in samples subjected to lower temperatures of hydrous pyrolysis (between $200^{\circ} \mathrm{C}$ and $240^{\circ} \mathrm{C}$ ). However, at the highest hydrous pyrolysis temperatures, representing the latest stages of postburial diagenesis, organic py-GC-MS responses from both sulfur streams were observed to be similar, both in terms of relative abundance and diversity. Another key difference between the samples was the much weaker intensity of the low mass peaks in the clay-rich samples, being almost undetectable in CR-Unmatured. This was consistent with the observation of lower relative jarosite abundances in the clay-rich samples compared to the clay-poor samples (Table 1).

\subsection{Clay-poor sulfur stream sample-alkali/acid treated}

Pyrolysis-GC-MS of the alkali/acid treated sulfur stream samples produced a much more prominent organic response 


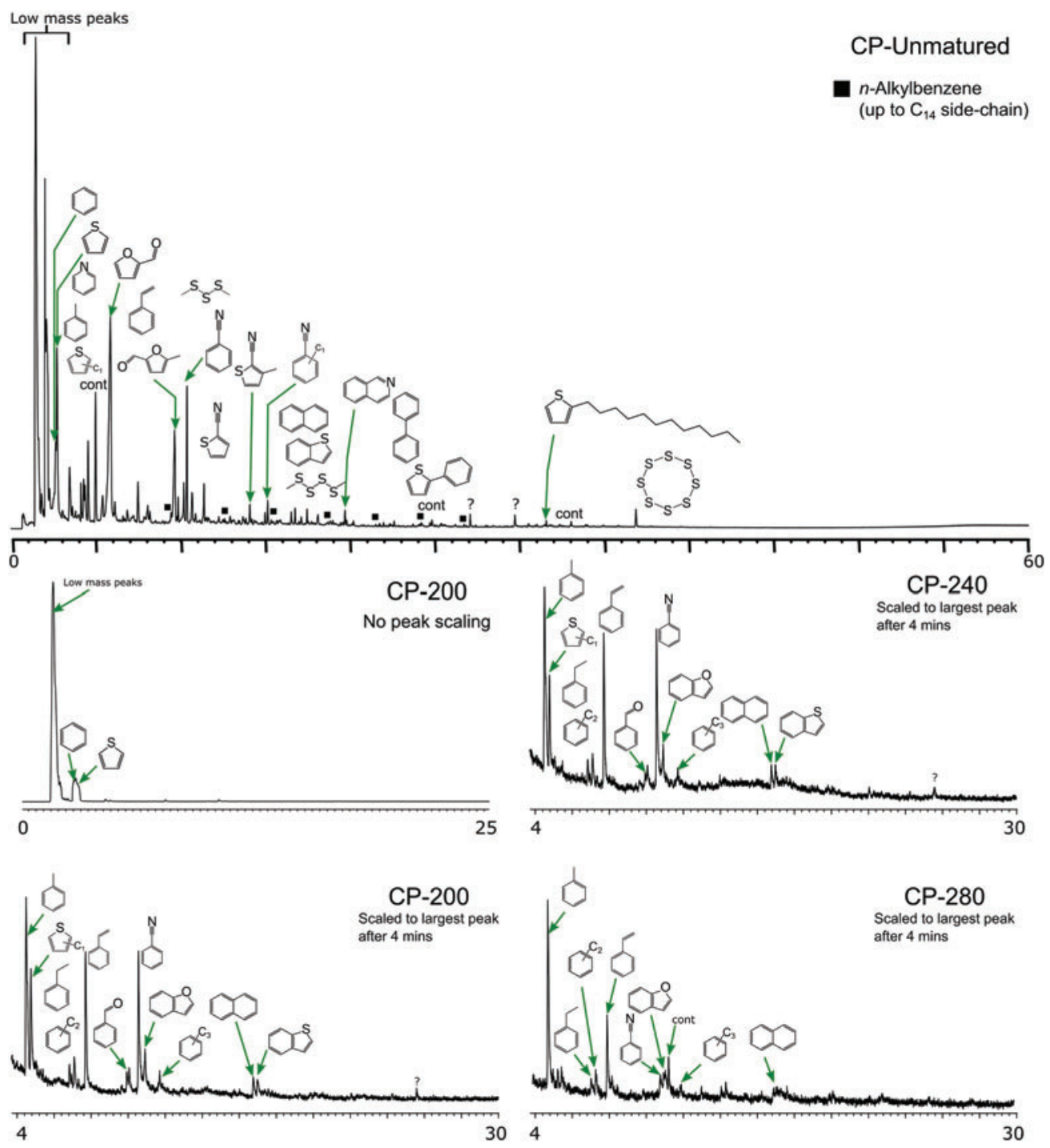

FIG. 2. Total ion current (TIC) chromatograms of the untreated clay-poor sulfur stream sample. Note that the samples that had been subjected to hydrous pyrolysis then subjected to py-GC-MS exhibited a low mass peak with a response much greater than the rest of the compounds, and thus had to be scaled to the largest peak after 4 min retention time. Color images are available online.

compared to samples that had not been subjected to treatment (Fig. 4). This was unsurprising, as the removal of mineral oxidants from the sulfur stream samples removes a potential source of evolved $\mathrm{O}_{2}$ that would interfere with the organic pyrolysis products generated during thermal decomposition.

Most of the py-GC-MS products that were observed in untreated samples (CP-Unmatured) were also observed in the treated samples (CP-Unmatured-A). Additional compounds generated by the py-GC-MS of CP-Unmatured-A included indenes, indoles, (benzo)furans, indanone, phenols, $n$-alkene and $n$-alkane pairs, $\mathrm{C}_{16}$ and $\mathrm{C}_{18}$ fatty acids, hopanes, maltol, and a significant amount of glucopyranose sugars. Fatty acids, maltol, and glucopyranose sugars have previously been observed as pyrolysis products of microbial mat material (Lewis et al., 2018), while phenols are known to be derived from the pyrolysis of lignin in higher plant material (Saiz-Jimenez and de Leeuw, 1984). Notably, (benzo)thiophenes were not observed in the alkali/acid treated samples despite being present in samples that had not been treated with alkali/acid.

Following the alkali/acid treatment, a much higher organic response was observed from the clay-poor samples subjected to hydrous pyrolysis (CP-200/240/280-A). This was expressed in a greater abundance and diversity of organic compounds. Additional classes of compounds that appeared after alkali/acid treatment included indenes, PAHs such as fluorene, phenanthrene, and fluoranthene, pyridines, indoles, alkylnitriles, indanone, phenols, $n$-alkene and $n$-alkane pairs, $\mathrm{C}_{16}$ and $\mathrm{C}_{18}$ fatty acids, and hopanes. The additional compounds represent a significant amount of diagnostic information that is lost when mineral oxidants are not removed from the sample prior to analysis.

It was also observed that many of these organic compounds were not lost despite transitioning from the early to late stages of simulated diagenesis. Some of the compounds 

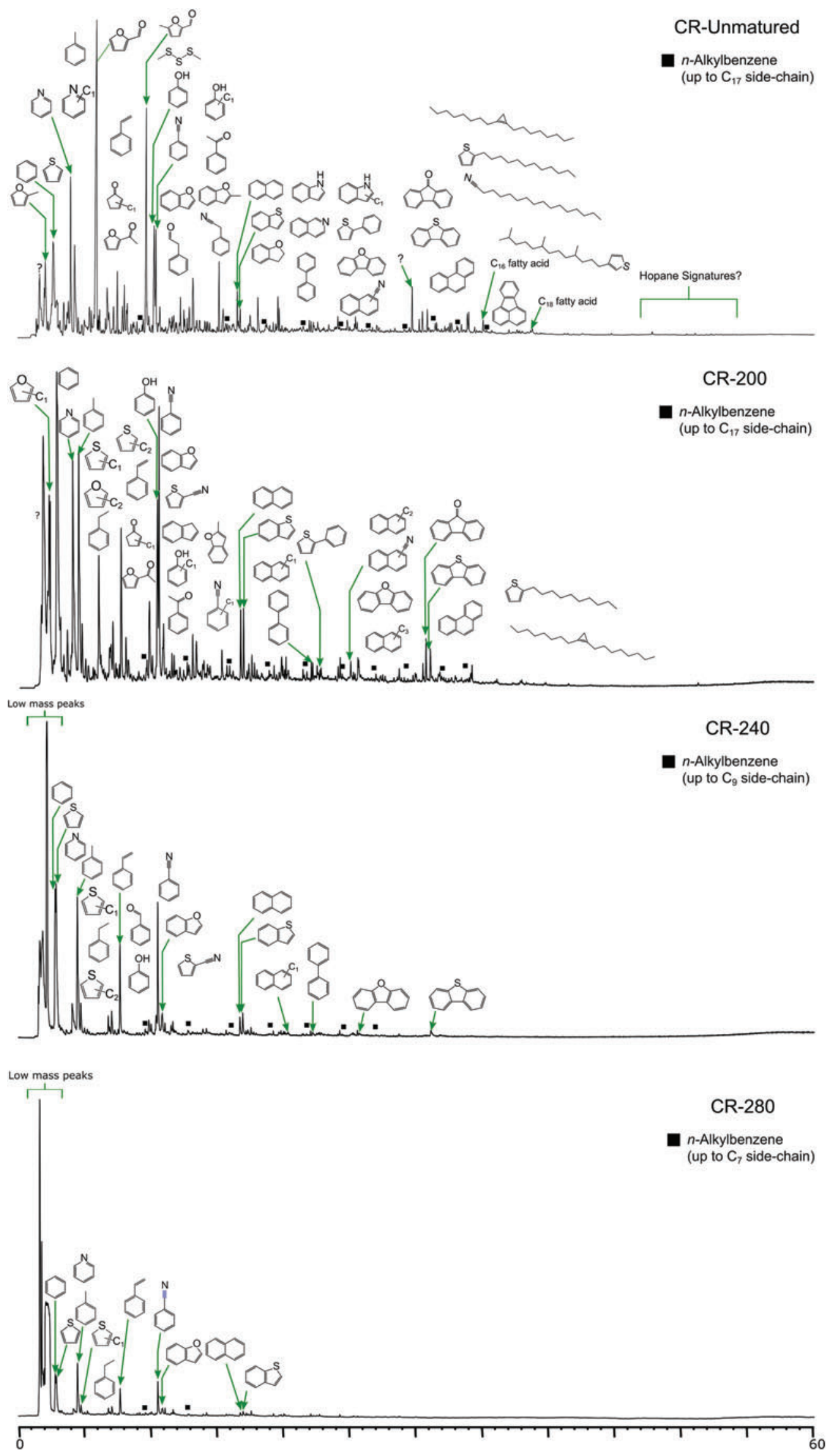

FIG. 3. TIC of the untreated clay-rich sulfur stream samples. Color images are available online. 


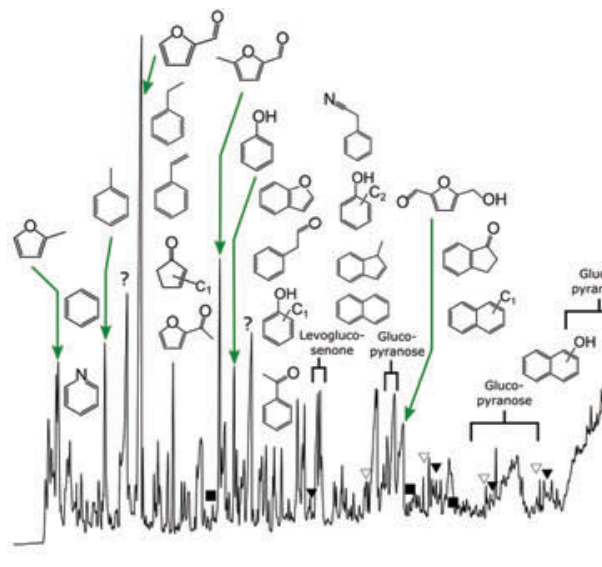

CP-Unmatured-A

$\nabla$ n-Alkene $\left(\mathrm{C}_{9}\right.$ to $\left.\mathrm{C}_{31}\right)$

$\boldsymbol{\nabla}$ n-Alkane $\left(\mathrm{C}_{9}\right.$ to $\left.\mathrm{C}_{31}\right)$

-Alkylbenzene

(up to $\mathrm{C}_{19}$ side-chain)
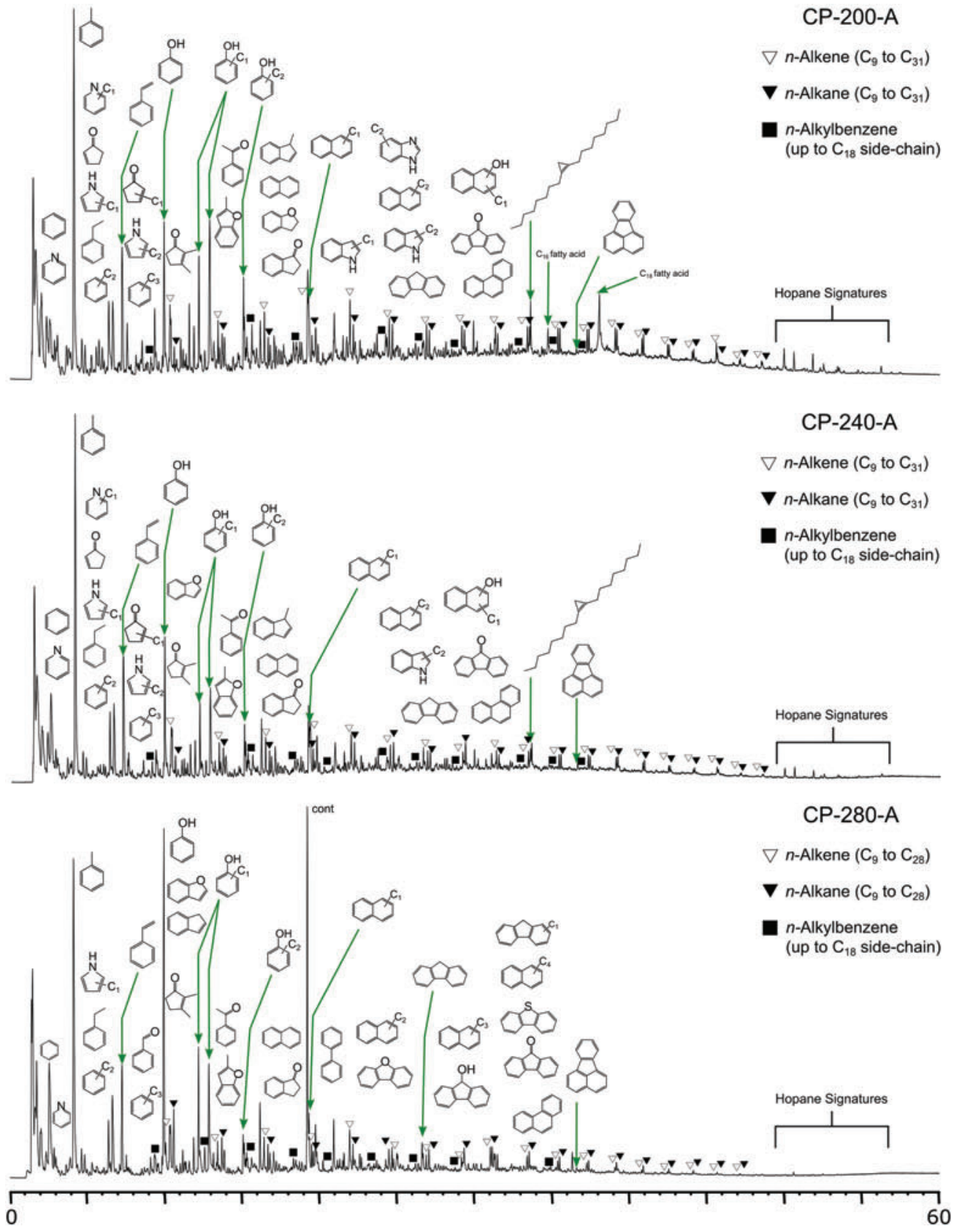

FIG. 4. TIC of the alkali/acid treated clay-poor sulfur stream samples. Color images are available online. 
that were lost during the process of artificial maturation included indoles (not observed in CP-280-A) and $n$-alkanoic fatty acids (not observed in CP-240-A or CP-280-A). Similar to the unmatured samples, no thiophenes or benzothiophenes were observed in the matured alkali/acid treated samples, with the exception of a small dibenzothiophene peak detected in CP-280-A. Additionally, no benzonitriles were observed in the matured alkali/acid treated samples, although, as mentioned above, other nitrile species such as alkylnitriles were present.

\subsection{Clay-rich sulfur stream sample-alkali/acid treated}

Similar to the alkali/acid treated clay-poor samples, clayrich samples treated with alkali/acid generated a greater organic response during py-GC-MS compared to samples that had not been treated (Fig. 5). The increased py-GC-MS organic response can be more clearly seen in the samples that have undergone artificial maturation by hydrous pyrolysis.

Additional organic compounds rendered detectable by pyGC-MS due to the removal of mineral oxidants include indene and glucopyranose sugars. Once again, no sulfur-containing organic compounds were observed in the alkali/acid treated sample, even though they were present in the untreated samples. In addition, no hopanes were detected in the unmatured sample; one possible explanation for the lack of py-GC-MS detectable hopanes in this sample is that the decanting of supernatants during the alkali/acid washes, may have removed the hopanoid fraction of the sample because it would have been water-soluble (Killops and Killops, 2005; Peters et al., 2005).

The effects of the alkali/acid treatment on the clay-poor samples were very similar to those seen in the clay-rich samples. Organic compounds rendered detectable by pyGC-MS following the removal of mineral oxidants included indoles, alkylnitriles, indenone, $n$-alkene and $n$-alkane pairs, $\mathrm{C}_{16}$ and $\mathrm{C}_{18}$ fatty acids, and hopanes. Furthermore, the abundance and diversity of these organic compounds did not change despite increasing levels of artificial maturation. While there was a loss in some individual species of organic compounds in CR-280-A, such as hexadecenoic acid and octadecanenitrile, in general many of the organic compounds observed in these samples were still detectable by py-GC-MS even at the latest stages of diagenesis.

\section{Discussion}

\subsection{Organic responses}

A multitude of organic compounds was produced by the sulfur stream during analysis by py-GC-MS (Table 3 ). This set of compounds is consistent with pyrolysis products generated from the pyrolysis of microbial mat material in similar geochemical environments (Lewis et al., 2018). The relatively large organic response in this sample is due to the significant amount of biological material hosted within the microbial mat, which can overcome the oxidative and catalytic effects of mineral oxidants (e.g., Royle et al., 2018a). As the samples were previously solvent extracted before py-GC-MS, the organic matter detected in these samples is either insoluble macromolecular material, organic matter that was bound to the surface of the mineral substrate, or organic material trapped within the crystal lattice of iron and sulfate minerals (Aubrey et al., 2006; François et al., 2016).

While several of the compounds detected in the pyrolysates are likely to be secondary pyrolysis products or otherwise cannot be unambiguously linked to a precursor molecule in the original sample, some of the compounds detected, especially the hopanes and presence of elevated levels of $\mathrm{C}_{16}$ and $\mathrm{C}_{18}$ alkanoic acids, are diagnostic of biology and could potentially be used as biosignatures.

Phenols are primarily derived from the pyrolysis of lignin in higher-order plant material (Saiz-Jimenez and de Leeuw, 1984); in this study, such responses may be the result of terrestrial contamination during the collection of the samples, or may be due to fossilized lignin that is common in the Cretaceous Wealden beds (Kemp et al., 2012). Phenols can also be derived from the pyrolysis of carbohydrates and proteins (Reeves and Francis, 1998). Furans and benzofurans are the pyrolysis products of carbohydrates (van Der Kaaden et al., 1983; Moldoveanu, 2010b), furfural is a dehydration product of sugars, and levoglucosenone and glucopyranose are the pyrolysis products of glycans and polysaccharide sugars (van Der Kaaden et al., 1983). $\mathrm{N}$-containing compounds including pyrroles, pyridines, and indoles are the pyrolysis products of proteins (Reeves and Francis, 1998). Alkylnitriles are possibly produced as an intermediate during the breakdown of N-containing compounds (such as fatty amides and fatty nitriles) to $n$-alkanes (Ishiwatari et al., 1992).

Thiophenes are generally not biological derivatives but are instead primarily formed by the abiogenic incorporation of sulfur into unsaturated moieties in a variety of organic compounds during early diagenesis. Thiophenes are then subsequently further incorporated into macromolecular networks (Kohnen et al., 1989; Sinninghe Damste et al., 1989). Homologous alkylbenzenes are produced during the decarboxylation, aromatization, and thermal cyclization of fatty acids, primarily as a function of pyrolysis rather than diagenetic effects (Traitler and Kratzl, 1980; Hartgers et al., 1995; Saiz-Jimenez, 1995, 1994). The incorporation of sulfur during this process may also result in the formation of alkylthiophenes (Saiz-Jimenez, 1995), which are observed in some samples, such as CR-Unmatured and CR-200. Similarly, $n$-alkenes and $n$-alkanes are also formed during flash pyrolysis, resulting from the decarboxylation of fatty acids or the thermal dissociation of aliphatic biopolymers (Hartgers et al., 1995; Versteegh et al., 2004).

$\mathrm{C}_{16}$ and $\mathrm{C}_{18}$ fatty acids are markers of bacterial cell membranes, while 1,2-dioctylcycloprop-1-ene, a cyclopropanoic alkene present in several samples, is likely to be derived from the decarboxylation of cyclopropyl fatty acids, which are markers of anaerobic bacteria (Vestal and White, 1989; Volkman et al., 1998). PAHs of varying molecular weights, such as indene, pyrene or fluoranthene, could be produced during the incomplete combustion of biopolymers (Severson et al., 1972), with the likely source being Cretaceous wood in the Wealden beds (Kemp et al., 2012). The origins of some specific PAHs could also be inferred; for example, phenanthrene is likely the product of the side chain removal and aromatization of abietic acid (Severson et al., 1972). However, many of the PAHs observed in the pyrolysis products of our samples may also have been produced 

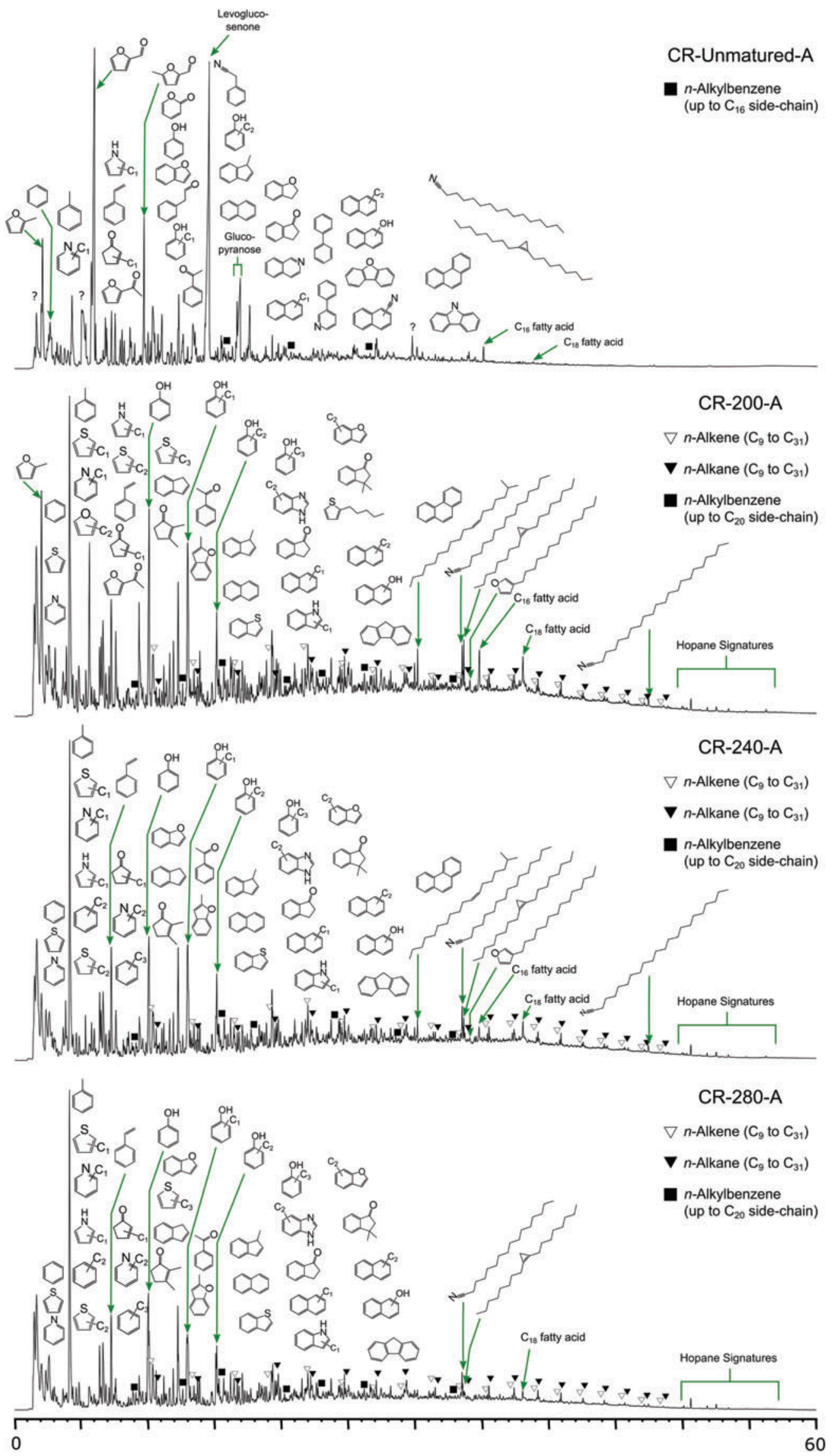

FIG. 5. TIC of the alkali/acid treated clay-rich sulfur stream samples. Color images are available online. 
Table 3. Potential Sources of Organic Compounds and Their Pyrolysis Products

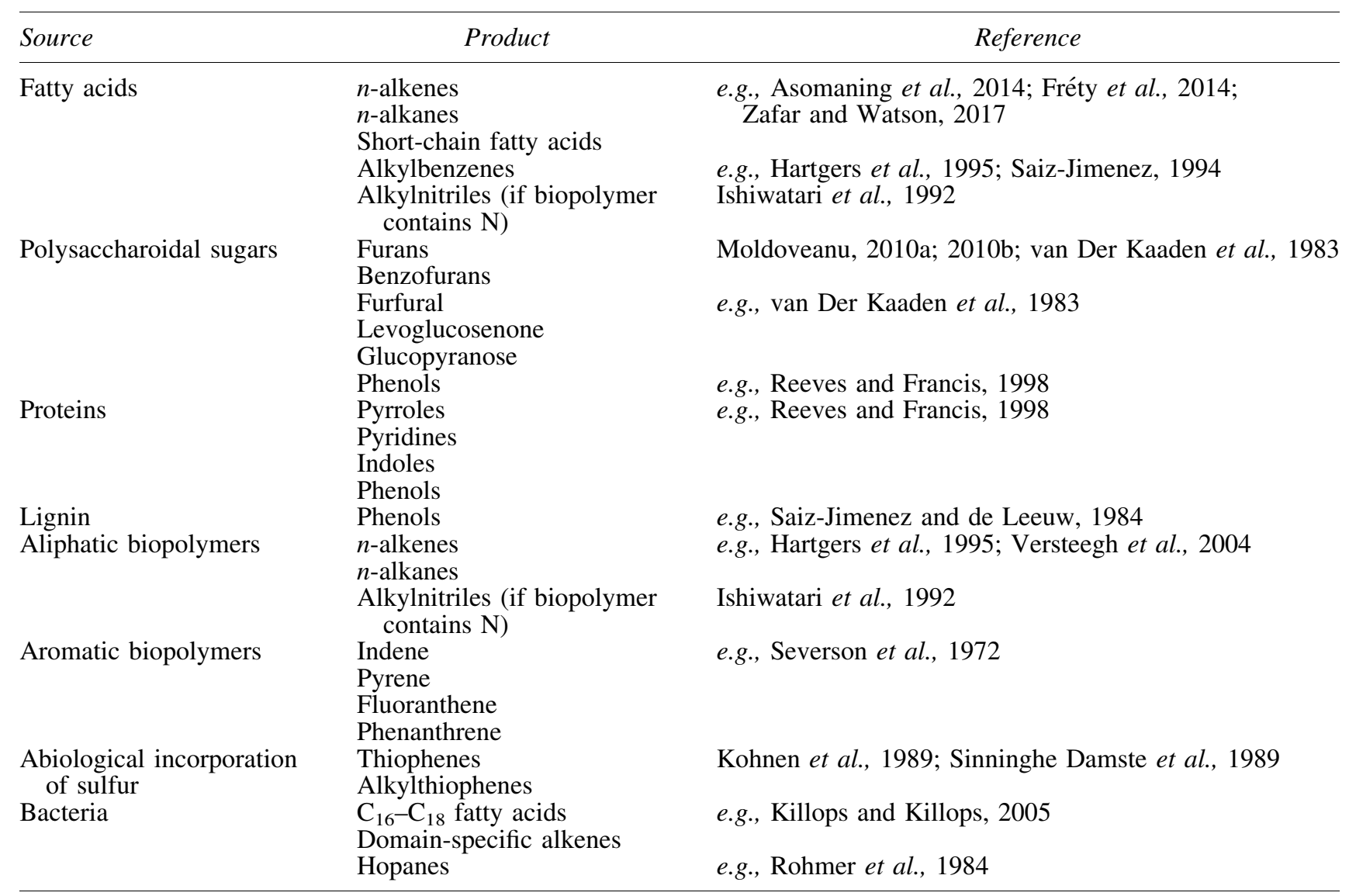

by the iron-oxide-catalyzed pyrolysis of simple organic compounds such as oleic acid (Watson and Sephton, 2015). PAHs can also be formed as secondary pyrolysis products via free radical substitutions from even simple aromatic compounds like benzene (Moldoveanu, 2010b). The PAH formation process is exacerbated by the presence of iron oxides, as $\mathrm{Fe}^{3+}$ will act as an electron acceptor, oxidizing the hydrocarbon molecule by scavenging $\mathrm{H}^{+}$ions. Free radicals are formed, which leads to cyclization and aromatization of aliphatic molecules as well as the formation of aryl free radicals which then react with other molecules to form dimers and further, higher-molecular-weight polymers, through oxidative coupling reactions (Grzybowski et al., 2013; Watson and Sephton, 2015). It is difficult to determine the origin of the PAHs formed in this sample, and to do so is outside the scope of this study.

Hopanes are diagnostic of bacteria, derived from bacteriohopanetetrol, and are key components of bacterial cell membranes (Rohmer et al., 1979, 1984). Depending on the hopanes, they may also be diagnostic of specific metabolisms, such as $\mathrm{C}_{31}-\mathrm{C}_{35}$ homohopanes being diagnostic of aerobic or microaerobic bacteria (Rohmer et al., 1984; Ourisson and Albrecht, 1992).

\subsection{Influence of mineralogy on organic matter detectability via py-GC-MS}

It is well known that oxidizing minerals such as jarosite can result in complications during the detection of organic matter because of the evolution of $\mathrm{O}_{2}$ during thermal decomposition (Hecht et al., 2009; Lewis et al., 2015), as well as mineral surface catalyzed transformative reactions (Watson and Sephton, 2015). Our results are consistent with the literature; the much greater diversity and magnitude of organic responses observed post-alkali/acid treatment reveals the extent to which oxidizing minerals interfere with and obfuscate the detection of organic compounds during py-GC-MS. It is possible to further study the interactions between organic and inorganic phases during py-GC-MS by analyzing the chromatograms of the samples in which mineral oxidants were not removed (i.e., the untreated samples).

Another explanation for the increased organic responses post-alkali/acid treatment is the presence of nonmacromolecular organic matter trapped within iron minerals. Such occluded minerals would be liberated during alkali/acid treatment. Trapped organics have already been observed in martian rocks and are released at higher pyrolysis temperatures $\left(>600^{\circ} \mathrm{C}\right)$ during evolved gas analyses conducted by the SAM instrument (François et al., 2016; Sutter et al., 2017). There is some evidence for the presence of trapped organic matter; carboxylic acids are observed in the treated samples. Such free nonpolar molecules should have been extracted during the initial pretreatment solvent extraction. Their presence in the macromolecular flash pyrolysis products suggests that they were initially occluded.

However, the occlusion of organic matter in minerals is unlikely to be the primary reason for increased organic 
responses in the treated samples. The intensity of the low mass peaks in the pretreated samples suggests a substantial amount of volatile production generated from the oxidation of organic matter resulting in $\mathrm{CO}_{2}$. In addition, there is evidence that a significant proportion of trapped organic material would have been ejected during hydrous pyrolysis as iron minerals are transformed and recrystallized to more stable iron species (Tan, unpublished data). Hence, there is evidence for both mechanisms at play, but oxidation by interaction with iron minerals is quantitatively the dominant process that results in a lowered organic response in the pretreated samples.

The clay-poor samples are shown to obfuscate organic detection by py-GC-MS much more than the clay-rich samples, despite both samples having similar organic matter inventories as shown by the abundance and diversity of organic responses once the oxidizing minerals were removed by alkali/acid treatment. One possibility for this behavior is the greater abundance of jarosite (10 vs. $6 \mathrm{wt} \%$ ) and goethite (26 vs. $18 \mathrm{wt} \%$ ) in the clay-poor samples compared to the clay-rich samples. Thiophenes are a known product of secondary reactions during flash pyrolysis, resulting from the sulfurization and aromatization of dienes via Diels-Alder reactions (Eigenbrode et al., 2015, 2018). This mechanism is a likely source for the abnormally large thiophene response observed in the untreated clay-poor samples (CP-Unmatured/200/240/280). In comparison, the clay-rich samples exhibit only minor responses of thiophene, and thiophene peaks are not observed in the final pyGC-MS products of the alkali/acid treated clay-poor samples. This suggests that secondary reactions are the primary source of thiophene formation in CP-Unmatured/200/240/ 280 , rather than being formed in situ via the incorporation of sulfur during diagenetic processes.

The slight variation in oxidizing mineral abundances is unlikely to fully account for the large differences in organic responses between the samples. Instead, another possible explanation would be the oxidation of organic matter by surface reactions. Previous work has shown that organic matter can be found bound to the surface of iron phases in sedimentary environments (Keil et al., 1994; Kaiser and Guggenberger, 2000; Lalonde et al., 2012); this is especially relevant in the case of fatty acids, where the negatively charged carboxylate ion is attracted to and binds with the positively charged iron oxide/oxyhydroxide surface (Kataby et al., 1999; Chernyshova et al., 2011; Wood et al., 2016). Saponification of the sulfur stream samples has shown that a significant amount of organic matter is bound to the goethite contained within these samples (Supplementary Fig. S4).

During py-GC-MS, free radicals $(\mathrm{H} \bullet$ and $\mathrm{OH} \bullet)$ produced during the reduction of iron oxides in the presence of organic matter and the products of iron oxide catalyzed water gas shift reactions would have promoted bond cleavage (Bouarab et al., 2014), leading to the highly deleterious oxidation of organic matter analogous to Fenton-style reactions (Foustoukos and Stern, 2012; Shuai et al., 2019). The presence of phenyl- and diphenyl-thiophene in the untreated clay-poor samples may indicate that $\mathrm{Fe}^{3+}$ oxidative coupling addition reactions are modifying the products of pyrolysis. Hydrogen abstraction (with corresponding $\mathrm{Fe}^{3+}$ reduction) creates free radicals, promoting dimerization and subsequent polymerization (Grzybowski et al., 2013; Wat- son and Sephton, 2015). The effects of these surface reactions, coupled with the secondary reactions involving $\mathrm{O}_{2}$ generated from the thermal decomposition of jarosite and/or goethite, would likely have produced features in the chromatograms obtained for the untreated clay-poor samples.

In contrast, the clay-rich samples contain a significant amount of clay content (36 wt \%) in the form of kaolinite and illite. Clays are similarly well known as sites for organic matter adsorption (Meyers and Quinn, 1971; Mayer, 1994; Bayrak, 2006; Zafar and Watson, 2017). Clays are known to have catalytic effects on adsorbed organic matter; unlike iron phases, however, the catalytic effects of clay do not result in the same degree of transformation of organic matter. Previous studies have shown that clay catalysis results in the breakdown of adsorbed material into simpler organic compounds, such as the generation of hydrocarbons by decarboxylation of fatty acids when pyrolyzed with bentonite (Jurg and Eisma, 1964; Shimoyama and Johns, 1971) or the breakdown of fatty acids into $n$-alk-1-enes, $n$-alkanes, and short-chain carboxylic acids when adsorbed onto kaolinite during py-GC-MS (Fréty et al., 2014; Zafar and Watson, 2017). During py-GC-MS, any organic material adsorbed onto clay surfaces is protected from iron oxide-facilitated surface reactions. Depending on the ratio of clay mineral surface area to iron mineral surface area, a significant amount of organic material may avoid deleterious surface reactions associated with iron-catalyzed free radical oxidation, and may account for the difference in the chromatograms of the untreated clay-rich and clay-poor samples (Figs. 2, 3).

It should be noted that while the untreated clay-rich samples returned a greater py-GC-MS organic response than their clay-poor counterparts during the early stages of diagenesis, this effect was muted at the later stages of diagenesis. This can be most clearly seen in CR-280, where a limited organic response and diversity were observed, while also being dwarfed by a large low mass peak. These observations suggest that while mineralogy has an observable effect on the detectability of organic material in sulfur streams py-GC-MS, this effect is reduced toward the later stages of diagenesis. One possible explanation for this behavior is that toward the later stages of simulated diagenesis, more organic matter is desorbed from the surface of the mineral substrates due to the increasing temperature and pressures. As a result, the influence of surface reactions during py-GC-MS lessens, and the final py-GC-MS products are more strongly dependent on the secondary reactions that occur as a result of the thermal decomposition of oxidizing minerals in the samples.

The implications of these results suggest that mineralogy is the primary control on the detection of organic matter via py-GC-MS. Specifically, the $\mathrm{O}_{2}$ and $\mathrm{SO}_{2}$ released by jarosite during thermal decomposition obfuscates organic matter detection (Lewis et al., 2015), while surface reactions on iron oxide substrates result in free radical oxidation of organic matter during pyrolysis. Clay minerals, however, provide an adsorption site for organic matter that is less deleterious compared to oxidizing minerals, and allows for the preservation and detection of organic matter via thermal extraction techniques.

It is important to note that this study only reports on the py-GC-MS products of organic matter on iron- and sulfurrich substrates. The specific mechanisms by which iron 
sulfates, oxides, and oxyhydroxides catalyze the transformation of organic compounds during py-GC-MS cannot be determined from these experiments, and to do so would be outside the scope of this work. Understanding the mechanisms behind the iron oxide-facilitated transformation of organic compounds requires more focused py-GC-MS experiments and should be the subject of further investigation.

\subsection{Influence of diagenesis on organic matter detectability via py-GC-MS}

Data from the untreated sulfur stream samples show that the elevated temperatures, pressures, and organic mattermineral interactions associated with diagenesis do have a significant effect on the detectability of organic matter. PyGC-MS organic responses decreased significantly with increased hydrous pyrolysis temperature, in both clay-rich and clay-poor samples. As mentioned in Section 4.2, we infer this to be due to the increased temperatures and pressures causing the cleavage of adsorptive bonds between the organic matter and the mineral substrates, rendering them susceptible to degradation. This effect has previously been seen in the solvent extracts of hydrously pyrolyzed samples (Tan and Sephton, 2019).

If iron- and sulfur-containing minerals are removed from the samples, however, the effect of diagenesis on the detectability of organic responses during py-GC-MS is more limited, but still observable. Between the early and late stages of simulated diagenesis, there is only a slight decrease in the organic response and diversity of both clayrich and clay-poor samples. Diagenesis can also result in the production of new compounds; thiophenes are observed in the treated clay-rich samples (CR-200/240/280-A), while they are absent in the unmatured clay-rich sample (CR-Unmatured). Unlike the thiophenes observed in CPUnmatured and CP-200/240/280, the thiophenes produced in CR-200/240/280-A are unlikely to be the product of secondary reactions due to the removal of jarosite by the alkali/acid treatment. Instead, they are likely produced during abiotic incorporation of sulfur during diagenesis (Kohnen et al., 1989; Sinninghe Damste et al., 1989).

It was observed that levoglucosenone and glucopyranose sugars are not preserved during the diagenetic process. Polysaccharidal material is thought to be prevented from entering the geosphere due to their rapid consumption by microbes. However, our data suggests that these sugars are also abiotically destroyed during diagenesis, as they are not detected in any of the samples that were subjected to artificial maturation, either in solvent extracts or pyrolysis chromatograms. This suggests that mineralogy can be an equally strong control on the preservation and degradation of these polysaccharides as compared to microbial metabolism.

In general, the lack of degradation associated with diagenesis is consistent with the refractory nature of macromolecular organic matter in terrestrial environments. Our data suggests that insoluble organic matter can be preserved over martian geological time, even in relatively oxidizing environments such as sulfur streams. Solvent extraction techniques may be inadequate for finding evidence of life on Mars, as they target the labile, soluble organic fraction on Mars which is susceptible to the effects of diagenesis (Tan and Sephton, 2019); macromolecular organic matter would be a more attractive target. However, the detection of organic matter, whether soluble or macromolecular, is obfuscated by effect of oxidizing minerals during thermal extraction techniques.

While our data is derived from the artificial maturation of primary biopolymers in relatively recent natural sediment samples from a Mars-analogue site on Earth, the formative and degradative mechanisms described here may provide insights into the processes involved in the formation of any insoluble organic macromolecules, that is, kerogens, on Mars, and their preservation over martian geological time.

\subsection{Influence of alkali/acid treatment on detectability via py-GC-MS}

Although organic matter can be detected without the removal of iron- and sulfur-containing minerals, even after being subjected to artificial maturation (organic responses, though small, were still observed in the clay-poor, untreated sulfur stream samples), it is important to consider the limitations of the lack of sample processing. None of the organic compounds observed in the untreated samples are unambiguously of biogenic origin. In addition, the samples analyzed in this study were taken from the center of the microbial mat, which likely held the highest concentration of organic matter in the environment. It has been shown that, if there is an abundance of organic matter above a critical threshold, it can be detected despite the presence of oxidizing minerals (Royle et al., 2018a); however, we cannot reasonably rely on sample selection strategies to find samples that contain organic matter in such high concentrations.

When iron- and sulfur-containing minerals were removed from the samples, however, the py-GC-MS organic response of the samples increased significantly. In addition, the removal of oxidizing minerals also reveals the presence of some organic information that would otherwise be inaccessible. In the case of this study, alkali/acid treatment revealed the presence of hopanes in the samples. The hopanes in these samples represent organic information that is unambiguously diagnostic of biogenic processes associated with the regulation of bacterial cell membranes (Rohmer et al., 1984, 1979); this information would be lost during pyrolysis if the oxidizing minerals were not removed during sample processing. The data highlights the amount of organic information that may be hidden by the interactions of organic and inorganic phases during py-GC-MS analysis.

As a contemporary example, evidence of refractory organic matter was detected at the base of the Murray Formation by the SAM suite on board the Curiosity rover (Eigenbrode et al., 2018). This included thiophenes, benzothiophenes, alkylbenzenes, chlorobenzenes, and naphthalene (Eigenbrode et al., 2018). However, the origin of the organic compounds detected could not be clearly defined (Eigenbrode et al., 2018). These mudstones contained jarosite, hematite, and magnetite, as well as an amorphous phase that may have contained ferrihydrite (Rampe et al., 2017). If these oxidizing minerals could have been removed from the sample prior to analysis, a significantly greater repository of organic information would have been unlocked, potentially providing greater insight as to the source of the refractory organics. 
As this study focuses primarily on iron- and sulfur-rich sediments, the alkali/acid treatments described here may not be directly relevant to all Mars missions. However, the results of this study will hopefully encourage further experiments and exploration into the efficacy of alternative sample handling protocols depending on geological context of the samples being tested, such as the washing of samples to remove perchlorates (Montgomery et al., 2019).

It should be noted that sample processing by itself does not guarantee that diagnostic information about the source of an organic sample will be revealed. Rather, sample processing gives scientists the best possible chance of detecting organic information that might potentially be able to distinguish biogenic organic matter from abiotic carbon, such as that from meteorites. Several studies have been conducted that show that abiogenic organic compounds such as those found in meteorites tend to display greater enantiomeric and structural diversity compared to their biogenic counterparts (e.g., Sephton and Botta, 2005). Well-preserved biogenic organic macromolecules can also be distinguished either by their structural specificity inherited from relatively resistant precursor molecules such as fatty acids and certain biopolymers (Matthewman et al., 2013). If the macromolecules have been subjected to significant reworking, biogenic and abiogenic organic matter can look very similar, but the vestiges of biological signals can still be recognized with close inspection (Matthewman et al., 2013).

\section{Conclusions}

Sulfur streams are appropriate analogues for the late Noachian and early Hesperian period of martian history, which may have exhibited surface conditions that were amenable to the emergence of martian life. For evidence of any martian life to be preserved and detected in the present day, organic matter must be stored for billions of years and avoid the effects of diagenesis, such as elevated temperatures and pressures, and the organic mattermineral interactions associated with burial in the subsurface. Furthermore, these organic fossils must be detectable by the instrument suites in use on current and future missions to Mars despite the interactions between organic and inorganic phases that may interfere with analysis and obfuscate results.

Hydrous pyrolysis allows researchers to simulate the effects of postburial diagenesis and gain insights into the behavior and nature of organic matter after geological storage over billions of years. Previous work has shown that soluble organic matter is poorly preserved in sulfur stream environments. This study shows that in sulfur stream environments, insoluble macromolecular organic matter can be preserved in the martian subsurface over billions of years, even accounting for the effects of postburial diagenesis.

The oxidizing minerals, such as jarosite and goethite, present in these environments pose a significant barrier to detection by thermal extraction strategies, such as py-GCMS. These minerals severely reduce organic responses due to the catalytic transformation of adsorbed organic matter through surface reactions during thermal decomposition. Clays are suggested to reduce the deleterious effect of jar- osite and goethite during flash pyrolysis experiments by providing a competing, nondeleterious adsorption site for organic matter. Should any oxidizing minerals be removed from the sample via simple preparative steps such as alkali and acid leaching, a significant amount of potentially diagnostic biogenic organic matter can be detected.

Therefore, when selecting samples for organic matter, sediments that contain jarosite and iron oxides and oxyhydroxides should be avoided. However, if the samples can be alkali and/or acid leached prior to analysis, a significant organic inventory that contains diagnostic, biogenic organic information may be revealed.

\section{Acknowledgments}

This work was supported by UK Space Agency grant ST/N000560/1 and an Imperial College President's PhD Scholarship granted to J. Tan.

\section{Author Disclosure Statement}

No competing financial interests exist.

\section{Supplementary Information}

Supplementary Figure S1

Supplementary Figure S2

Supplementary Figure S3

Supplementary Figure S4

\section{References}

Amils, R., González-Toril, E., Fernández-Remolar, D., Gómez, F., Aguilera, Á., Rodríguez, N., Malki, M., García-Moyano, A., Fairén, A.G., de la Fuente, V., and Luis Sanz, J. (2007) Extreme environments as Mars terrestrial analogs: The Río Tinto case. Planet Space Sci 55:370-381.

Anderson, D.M., Biemann, K., Orgel, L.E., Oro, J., Owen, T., Shulman, G.P., Toulmin, P., and Urey, H.C. (1972) Mass spectrometric analysis of organic compounds, water and volatile constituents in the atmosphere and surface of Mars: the Viking Mars lander. Icarus 16:111-138.

Asomaning, J., Mussone, P., and Bressler, D.C. (2014) Pyrolysis of polyunsaturated fatty acids. Fuel Process Technol 120:89-95.

Aubrey, A., Cleaves, H.J., Chalmers, J.H., Skelley, A.M., Mathies, R.A., Grunthaner, F.J., Ehrenfreund, P., and Bada, J.L. (2006) Sulfate minerals and organic compounds on Mars. Geology 34:357-360.

Bayrak, Y. (2006) Application of Langmuir isotherm to saturated fatty acid adsorption. Microporous Mesoporous Mater 87:203-206.

Beegle, L., Bhartia, R., White, M., Deflores, L., Abbey, W., Wu, Y.H., Cameron, B., Moore, J., Fries, M., Burton, A., Edgett, K.S., Ravine, M.A., Hug, W., Reid, R., Nelson, T., Clegg, S., Wiens, R., Asher, S., and Sobron, P. (2015) SHERLOC: Scanning Habitable Environments with Raman \& Luminescence for Organics \& Chemicals. In 2015 Aerospace Conference, IEEE, Piscataway, NJ, doi:10.1109/ AERO.2015.7119105.

Benison, K.C., and Bowen, B.B. (2006) Acid saline lake systems give clues about past environments and the search for life on Mars. Icarus 183, 225-229.

Bibring, J.-P., Langevin, Y., Mustard, J.F., Poulet, F., Arvidson, R., Gendrin, A., Gondet, B., Mangold, N., Pinet, P, Forget, F, 
Berthé, M., Bibring, J.-P., Gendrin, A., Gomez, C., Gondet, B., Jouglet, D., Poulet, F., Soufflot, A., Vincendon, M., Combes, M., Drossart, P., Encrenaz, T., Fouchet, T., Merchiorri, R., Belluci, G., Altieri, F., Formisano, V., Capaccioni, F., Cerroni, P., Coradini, A., Fonti, S., Korablev, O., Kottsov, V., Ignatiev, N., Moroz, V., Titov, D., Zasova, L., Loiseau, D., Mangold, N., Pinet, P., Douté, S., Schmitt, B., Sotin, C., Hauber, E., Hoffmann, H., Jaumann, R., Keller, U., Arvidson, R., Mustard, J.F., Duxbury, T., Forget, F., and Neukum, G. (2006) Global mineralogical and aqueous Mars history derived from OMEGA/ Mars Express data. Science 312:400-404.

Biemann, K., Oro, J., Toulmin, P., Orgel, L.E., Nier, A.O., Anderson, D.M., Simmonds, P.G., Flory, D., Diaz, A.V., Rushneck, D.R., Biller, J.E., and Lafleur, A.L. (1977) The search for organic substances and inorganic volatile compounds in the surface of Mars. J Geophys Res 82:4641-4658.

Bigham, J.M., and Nordstrom, D.K. (2000) Iron and aluminum hydroxysulfates from acid sulfate waters. Rev Mineral Geochemistry 40:847-853.

Borlina, C.S., Ehlmann, B.L., and Kite, E.S. (2015) Modeling the thermal and physical evolution of Mount Sharp's sedimentary rocks, Gale Crater, Mars: implications for diagenesis on the MSL Curiosity rover traverse. J Geophys Res Planets 120:1396-1414.

Bouarab, R., Bennici, S., Mirodatos, C., and Auroux, A. (2014) Hydrogen production from the water-gas shift reaction on iron oxide catalysts. J Catal 2014, doi:10.1155/2014/612575.

Brinckerhoff, W.B., Pinnick, V.T., Van Amerom, F.H.W., Danell, R.M., Arevalo, R.D., Atanassova, M.S., Li, X., Mahaffy, P.R., Cotter, R.J., Goesmann, F., and Steininger, H. (2013) Mars Organic Molecule Analyzer (MOMA) mass spectrometer for ExoMars 2018 and beyond. In 2013 Aerospace Conference, IEEE, Piscataway, NJ, doi:10.1109/AERO.2013.6496942

Brocks, J.J., and Summons, R.E. (2004) Sedimentary hydrocarbons, biomarkers for early life. In Treatise on Geochemistry, 2nd ed., Vol 8. Elsevier, Amsterdam, doi:10.1016/ B978-0-08-095975-7.00803-2.

Brocks, J.J., Logan, G.A., Buick, R., and Summons, R.E. (1999) Archean molecular fossils and the early rise of eukaryotes. Science 285:1033-1036.

Burns, R.G. (1987) Gossans on Mars: spectral features attributed to jarosite [absract 1072]. In 18th Lunar and Planetary Science Conference, Lunar and Planetary Institute, Houston.

Caswell, T.E., and Milliken, R.E. (2017) Evidence for hydraulic fracturing at Gale crater, Mars: implications for burial depth of the Yellowknife Bay formation. Earth Planet Sci Lett 468: 72-84.

Chernyshova, I.V., Ponnurangam, S., and Somasundaran, P. (2011). Adsorption of fatty acids on iron (hydr)oxides from aqueous solutions. Langmuir 27:10007-10018.

Cockell, C.S. (2014) Trajectories of martian habitability. Astrobiology 14:182-203.

Colín-García, M., Kanawati, B., Harir, M., Schmitt-Kopplin, P., Amils, R., Parro, V., García, M., and Fernández-Remolar, D. (2011) Detection of peptidic sequences in the ancient acidic sediments of Río Tinto, Spain. Orig Life Evol Biosph 41:523-527.

Dartnell, L.R. (2011) Ionizing radiation and life. Astrobiology 11:551-582.

Des Marais, D.J., Nuth, J.A., Allamandola, L.J., Boss, A.P., Farmer, J.D., Hoehler, T.M., Jakosky, B.M., Meadows, V.S., Pohorille, A., Runnegar, B., and Spormann, A.M. (2008) The NASA Astrobiology Roadmap. Astrobiology 8:715-730.

Edgett, K.S., Schieber, J., Grotzinger, J.P., Siebach, K.L., Stack, K.M., Edgar, L.A., Gasda, P.J., Frydenvang, J., Gupta, S.,
Kronyak, R.E., and Kah, L.C. (2016) Depth of burial for lithification and diagenesis of muds and sands on early Mars. In SEPM/AAPG Hedberg Research Conference, Santa Fe, NM, doi:10.1126/science.aac7575.

Eglinton, T.I., and Douglas, A.G. (1988) Quantitative study of biomarker hydrocarbons released from kerogens during hydrous pyrolysis. Energy and Fuels 2:81-88.

Ehlmann, B.L., Mustard, J.F., Murchie, S.L., Bibring, J.-P., Meunier, A., Fraeman, A.A., and Langevin, Y. (2011) Subsurface water and clay mineral formation during the early history of Mars. Nature 479:53-60.

Eigenbrode, J.L., Steele, A., Summons, R.E., Sutter, B., McAdam, A.C., Franz, H.B., Mahaffy, P.R., Conrad, P.G., Freissinet, C., Glavin, D.P., Millan, M., and Ming, D.W. (2015) Evidence of refractory organic matter preserved in the mudstones of Yellowknife Bay and the Murray Formations [\#79168]. In 2015 AGU Fall Meeting Abstracts, American Geophysical Union, Washington, DC.

Eigenbrode, J.L., Summons, R.E., Steele, A., Freissinet, C., Millan, M., Navarro-González, R., Sutter, B., McAdam, A.C., Franz, H.B., Glavin, D.P., Archer, P.D., Mahaffy, P.R., Conrad, P.G., Hurowitz, J.A., Grotzinger, J.P., Gupta, S., Ming, D.W., Sumner, D.Y., Szopa, C., Malespin, C., Buch, A., and Coll, P. (2018) Organic matter preserved in 3-billion-year-old mudstones at Gale crater, Mars. Science 360:1096-1101.

Fernández-Remolar, D.C., and Knoll, A.H. (2008) Fossilization potential of iron-bearing minerals in acidic environments of Río Tinto, Spain: implications for Mars exploration. Icarus 194:72-85.

Fernández-Remolar, D.C., Morris, R.V., Gruener, J.E., Amils, R., and Knoll, A.H. (2005) The Río Tinto Basin, Spain: mineralogy, sedimentary geobiology, and implications for interpretation of outcrop rocks at Meridiani Planum, Mars. Earth Planet Sci Lett 240:149-167.

Ferris, F.G., Tazaki, K., and Fyfe, W.S. (1989) Iron oxides in acid mine drainage environments and their association with bacteria. Chem Geol 74:321-330.

Foustoukos, D.I., and Stern, J.C. (2012) Oxidation pathways for formic acid under low temperature hydrothermal conditions: implications for the chemical and isotopic evolution of organics on Mars. Geochim Cosmochim Acta 76:14-28.

François, P., Szopa, C., Buch, A., Coll, P., McAdam, A.C., Mahaffy, P.R., Freissinet, C., Glavin, D.P., NavarroGonzalez, R., and Cabane, M. (2016) Magnesium sulfate as a key mineral for the detection of organic molecules on Mars using pyrolysis. J Geophys Res Planets 121: 61-74.

Fréty, R., Pacheco, J.G.A., Santos, M.R., Padilha, J.F., Azevedo, A.F., Brandão, S.T., and Pontes, L.A.M. (2014) Flash pyrolysis of model compounds adsorbed on catalyst surface: a method for screening catalysts for cracking of fatty molecules. J Anal Appl Pyrolysis 109:56-64.

Gaillard, F., Michalski, J., Berger, G., McLennan, S.M., and Scaillet, B. (2013) Geochemical reservoirs and timing of sulfur cycling on Mars. Space Sci Rev 174:251-300.

Gendrin, A., Mangold, N., Bibring, J.-P., Langevin, Y., Gondet, B., Poulet, F., Bonello, G., Quantin, C., Mustard, J., Arvidson, R., and LeMouélic, S. (2005) Sulfates in martian layered terrains: the OMEGA/Mars Express view. Science 307:1587-1591.

Glavin, D.P., Freissinet, C., Miller, K.E., Eigenbrode, J.L., Brunner, A.E., Buch, A., Sutter, B., Archer, P.D., Atreya, S.K., Brinckerhoff, W.B., Cabane, M., Coll, P., Conrad, P.G., Coscia, D., Dworkin, J.P., Franz, H.B., Grotzinger, J.P., Leshin, L.A., Martin, M.G., McKay, C., Ming, D.W., NavarroGonzalez, R., Pavlov, A., Steele, A., Summons, R.E., Szopa, 
C., Teinturier, S., and Mahaffy, P.R. (2013) Evidence for perchlorates and the origin of chlorinated hydrocarbons detected by SAM at the Rocknest aeolian deposit in Gale Crater. J Geophys Res Planets 118:1955-1973.

Goesmann, F., Brinckerhoff, W.B., Raulin, F., Goetz, W., Danell, R.M., Getty, S.A., Siljeström, S., Mißbach, H., Steininger, H., Arevalo, R.D., Buch, A., Freissinet, C., Grubisic, A., Meierhenrich, U.J., Pinnick, V.T., Stalport, F., Szopa, C., Vago, J.L., Lindner, R., Schulte, M.D., Brucato, J.R., Glavin, D.P., Grand, N., Li, X., van Amerom, F.H.W., and the MOMA Science Team. (2017) The Mars Organic Molecule Analyzer (MOMA) instrument: characterization of organic material in martian sediments. Astrobiology 17:655-685.

Goetz, W., Brinckerhoff, W.B., Arevalo, R., Freissinet, C., Getty, S., Glavin, D.P., Siljeström, S., Buch, A., Stalport, F., Grubisic, A., Li, X., Pinnick, V., Danell, R., van Amerom, F.H.W., Goesmann, F., Steininger, H., Grand, N., Raulin, F., Szopa, C., Meierhenrich, U., and Brucato, J.R. (2016) MOMA: the challenge to search for organics and biosignatures on Mars. Int J Astrobiol 15:239-250.

Grotzinger, J.P., Crisp, J., Vasavada, A.R., Anderson, R.C., Baker, C.J., Barry, R., Blake, D.F., Conrad, P., Edgett, K.S., Ferdowski, B., Gellert, R., Gilbert, J.B., Golombek, M., Gómez-Elvira, J., Hassler, D.M., Jandura, L., Litvak, M., Mahaffy, P., Maki, J., Meyer, M., Malin, M.C., Mitrofanov, I., Simmonds, J.J., Vaniman, D., Welch, R.V., and Wiens, R.C. (2012) Mars Science Laboratory mission and science investigation. Space Sci Rev 170:5-56.

Grzybowski, M., Skonieczny, K., Butenschön, H., and Gryko, D.T. (2013) Comparison of oxidative aromatic coupling and the Scholl reaction. Angew Chemie Int Ed Engl 52:99009930.

Guinn, J.R., Garcia, M.D., and Talley, K. (2008) Mission design of the Phoenix Mars Scout mission. J Geophys Res 113, doi: 10.1029/2007JE003038.

Hartgers, W.A., Sinninghe Damsté, J.S., and de Leeuw, J.W. (1995) Curie-point pyrolysis of sodium salts of functionalized fatty acids. J Anal Appl Pyrolysis 34:191-217.

Hassler, D.M., Zeitlin, C., Wimmer-Schweingruber, R.F., Ehresmann, B., Rafkin, S., Eigenbrode, J.L., Brinza, D.E., Weigle, G., Bottcher, S., Bohm, E., Burmeister, S., Guo, J., Kohler, J., Martin, C., Reitz, G., Cucinotta, F.A., Kim, M.-H., Grinspoon, D., Bullock, M.A., Posner, A., Gomez-Elvira, J., Vasavada, A., Grotzinger, J.P., Team, M.S., Kemppinen, O., Cremers, D., Bell, J.F., Edgar, L., Farmer, J., Godber, A., Wadhwa, M., Wellington, D., McEwan, I., Newman, C., Richardson, M., Charpentier, A., Peret, L., King, P., Blank, J., Schmidt, M., Li, S., Milliken, R., Robertson, K., Sun, V., Baker, M., Edwards, C., Ehlmann, B., Farley, K., Griffes, J., Miller, H., Newcombe, M., Pilorget, C., Rice, M., Siebach, K., Stack, K., Stolper, E., Brunet, C., Hipkin, V., Leveille, R., Marchand, G., Sanchez, P.S., Favot, L., Cody, G., Steele, A., Fluckiger, L., Lees, D., Nefian, A., Martin, M., Gailhanou, M., Westall, F., Israel, G., Agard, C., Baroukh, J., Donny, C., Gaboriaud, A., Guillemot, P., Lafaille, V., Lorigny, E., Paillet, A., Perez, R., Saccoccio, M., Yana, C., ArmiensAparicio, C., Rodriguez, J.C., Blazquez, I.C., Gomez, F.G., Hettrich, S., Malvitte, A.L., Jimenez, M.M., Martinez-Frias, J., Martin-Soler, J., Martin-Torres, F.J., Jurado, A.M., MoraSotomayor, L., Caro, G.M., Lopez, S.N., Peinado-Gonzalez, V., Pla-Garcia, J., Manfredi, J.A.R., Romeral-Planello, J.J., Fuentes, S.A.S., Martinez, E.S., Redondo, J.T., UrquiO'Callaghan, R., Mier, M.-P.Z., Chipera, S., Lacour, J.-L., Mauchien, P., Sirven, J.-B., Manning, H., Fairen, A., Hayes,
A., Joseph, J., Squyres, S., Sullivan, R., Thomas, P., Dupont, A., Lundberg, A., Melikechi, N., Mezzacappa, A., Berger, T., Matthia, D., Prats, B., Atlaskin, E., Genzer, M., Harri, A.-M., Haukka, H., Kahanpaa, H., Kauhanen, J., Kemppinen, O., Paton, M., Polkko, J., Schmidt, W., Siili, T., Fabre, C., Wray, J., Wilhelm, M.B., Poitrasson, F., Patel, K., Gorevan, S., Indyk, S., Paulsen, G., Gupta, S., Bish, D., Schieber, J., Gondet, B., Langevin, Y., Geffroy, C., Baratoux, D., Berger, G., Cros, A., D’Uston, C., Forni, O., Gasnault, O., Lasue, J., Lee, Q.-M., Maurice, S., Meslin, P.-Y., Pallier, E., Parot, Y., Pinet, P., Schroder, S., Toplis, M., Lewin, E., Brunner, W., Heydari, E., Achilles, C., Oehler, D., Sutter, B., Cabane, M., Coscia, D., Israel, G., Szopa, C., Dromart, G., Robert, F., Sautter, V., Le Mouelic, S., Mangold, N., Nachon, M., Buch, A., Stalport, F., Coll, P., Francois, P., Raulin, F., Teinturier, S., Cameron, J., Clegg, S., Cousin, A., DeLapp, D., Dingler, R., Jackson, R.S., Johnstone, S., Lanza, N., Little, C., Nelson, T., Wiens, R.C., Williams, R.B., Jones, A., Kirkland, L., Treiman, A., Baker, B., Cantor, B., Caplinger, M., Davis, S., Duston, B., Edgett, K., Fay, D., Hardgrove, C., Harker, D., Herrera, P., Jensen, E., Kennedy, M.R., Krezoski, G., Krysak, D., Lipkaman, L., Malin, M., McCartney, E., McNair, S., Nixon, B., Posiolova, L., Ravine, M., Salamon, A., Saper, L., Stoiber, K., Supulver, K., Van Beek, J., Van Beek, T., Zimdar, R., French, K.L., Iagnemma, K., Miller, K., Summons, R., Goesmann, F., Goetz, W., Hviid, S., Johnson, M., Lefavor, M., Lyness, E., Breves, E., Dyar, M.D., Fassett, C., Blake, D.F., Bristow, T., Des Marais, D., Edwards, L., Haberle, R., Hoehler, T., Hollingsworth, J., Kahre, M., Keely, L., McKay, C., Wilhelm, M.B., Bleacher, L., Brinckerhoff, W., Choi, D., Conrad, P., Dworkin, J.P., Floyd, M., Freissinet, C., Garvin, J., Glavin, D., Harpold, D., Jones, A., Mahaffy, P., Martin, D.K., McAdam, A., Pavlov, A., Raaen, E., Smith, M.D., Stern, J., Tan, F., Trainer, M., Meyer, M., Voytek, M., Anderson, R.C., Aubrey, A., Beegle, L.W., Behar, A., Blaney, D., Calef, F., Christensen, L., Crisp, J.A., DeFlores, L., Ehlmann, B., Feldman, J., Feldman, S., Flesch, G., Hurowitz, J., Jun, I., Keymeulen, D., Maki, J., Mischna, M., Morookian, J.M., Parker, T., Pavri, B., Schoppers, M., Sengstacken, A., Simmonds, J.J., Spanovich, N., Juarez, M.d.1.T., Webster, C.R., Yen, A., Archer, P.D., Jones, J.H., Ming, D., Morris, R.V., Niles, P., Rampe, E., Nolan, T., Fisk, M., Radziemski, L., Barraclough, B., Bender, S., Berman, D., Dobrea, E.N., Tokar, R., Vaniman, D., Williams, R.M.E., Yingst, A., Lewis, K., Leshin, L., Cleghorn, T., Huntress, W., Manhes, G., Hudgins, J., Olson, T., Stewart, N., Sarrazin, P., Grant, J., Vicenzi, E., Wilson, S.A., Hamilton, V., Peterson, J., Fedosov, F., Golovin, D., Karpushkina, N., Kozyrev, A., Litvak, M., Malakhov, A., Mitrofanov, I., Mokrousov, M., Nikiforov, S., Prokhorov, V., Sanin, A., Tretyakov, V., Varenikov, A., Vostrukhin, A., Kuzmin, R., Clark, B., Wolff, M., McLennan, S., Botta, O., Drake, D., Bean, K., Lemmon, M., Schwenzer, S.P., Anderson, R.B., Herkenhoff, K., Lee, E.M., Sucharski, R., Hernandez, M.A.d.P., Avalos, J.J.B., Ramos, M., Malespin, C., Plante, I., Muller, J.-P., Navarro-Gonzalez, R., Ewing, R., Boynton, W., Downs, R., Fitzgibbon, M., Harshman, K., Morrison, S., Dietrich, W., Kortmann, O., Palucis, M., Sumner, D.Y., Williams, A., Lugmair, G., Wilson, M.A., Rubin, D., Jakosky, B., Balic-Zunic, T., Frydenvang, J., Jensen, J.K., Kinch, K., Koefoed, A., Madsen, M.B., Stipp, S.L.S., Boyd, N., Campbell, J.L., Gellert, R., Perrett, G., Pradler, I., VanBommel, S., Jacob, S., Owen, T., Rowland, S., Atlaskin, E., Savijarvi, H., Garcia, C.M., Mueller-Mellin, R., Bridges, J.C., McConnochie, T., Benna, 
M., Franz, H., Bower, H., Brunner, A., Blau, H., Boucher, T., Carmosino, M., Atreya, S., Elliott, H., Halleaux, D., Renno, N., Wong, M., Pepin, R., Elliott, B., Spray, J., Thompson, L., Gordon, S., Newsom, H., Ollila, A., Williams, J., Vasconcelos, P., Bentz, J., Nealson, K., Popa, R., Kah, L.C., Moersch, J., Tate, C., Day, M., Kocurek, G., Hallet, B., Sletten, R., Francis, R., McCullough, E., Cloutis, E., ten Kate, I.L., Kuzmin, R., Arvidson, R., Fraeman, A., Scholes, D., Slavney, S., Stein, T., Ward, J., Berger, J., and Moores, J.E. (2014) Mars' surface radiation environment measured with the Mars Science Laboratory's Curiosity rover. Science 343, doi:10.1126/science.1244797.

Hecht, M.H., Kounaves, S.P., Quinn, R.C., West, S.J., Young, S.M.M., Ming, D.W., Catling, D.C., Clark, B.C., Boynton, W.V., Hoffmann, J., DeFlores, L., Gospodinova, K., Kapit, J., and Smith, P.H. (2009) Detection of perchlorate and the soluble chemistry of martian soil at the Phoenix lander site. Science 325:64-67.

Hoffman, N. (2001) Modern geothermal gradients on Mars and implications for subsurface liquids [abstract 7044]. In Conference on the Geophysical Detection of Subsurface Water on Mars, Lunar and Planetary Institute, Houston.

Horneck, G., Walter, N., Westall, F., Grenfell, J.L., Martin, W.F., Gomez, F., Leuko, S., Lee, N., Onofri, S., Tsiganis, K., Saladino, R., Pilat-Lohinger, E., Palomba, E., Harrison, J., Rull, F., Muller, C., Strazzulla, G., Brucato, J.R., Rettberg, P., and Capria, M.T. (2016) AstRoMap European Astrobiology Roadmap. Astrobiology 16:201-243.

Ishiwatari, R., Sugawara, S., and Machihara, T. (1992) Longchain aliphatic nitriles in pyrolysates of young kerogen: implications for the intermediates in petroleum hydrocarbon formation. Geochem J 26:137-146.

Jaeschke, A., Lewan, M.D., Hopmans, E.C., Schouten, S., and Sinninghe Damsté, J.S. (2008) Thermal stability of ladderane lipids as determined by hydrous pyrolysis. Org Geochem 39: 1735-1741.

Jurg, J.W., and Eisma, E. (1964) Petroleum hydrocarbons: generation from fatty acid. Science 144:1451-1452.

Kaiser, K., and Guggenberger, G. (2000) The role of DOM sorption to mineral surfaces in the preservation of organic matter in soils. Org Geochem 31:711-725.

Kaplan, H.H., Milliken, R.E., Fernández-Remolar, D., Amils, R., Robertson, K., and Knoll, A.H. (2016) Orbital evidence for clay and acidic sulfate assemblages on Mars based on mineralogical analogs from Río Tinto, Spain. Icarus 275:45-64.

Kataby, G., Cojocaru, M., Prozorov, R., and Gedanken, A. (1999) Coating carboxylic acids on amorphous iron nanoparticles. Langmuir 15:1703-1708.

Keil, R.G., Montlucon, D.B., Prahl, F.G., and Hedges, J.I. (1994) Sorptive preservation of labile organic matter in marine sediments. Nature 370:549-552.

Kemp, S.J., Wagner, D., and Ingham, M.N. (2012) The Mineralogy, Surface Area and Geochemistry of Samples from the Wealden Group of Southern England, BGS Internal Report IR/10/079, British Geological Survey, Nottingham, UK.

Killops, S., and Killops, V. (2005) Introduction to Organic Geochemistry, Blackwell Publishing, Malden, MA.

Klingelhöfer, G., Morris, R.V., Bernhardt, B., Schröder, C., Rodionov, D.S., De Souza, P.A., Yen, A.S., Gellert, R., Evlanov, E.N., Zubkov, B., Foh, J., Bonnes, U., Kankeleit, E., Gutlich, P., Ming, D.W., Renz, F., Wdowiak, T., Squyres, S.W., and Arvidson, R.E. (2004) Jarosite and hematite at Meridiani Planum from Opportunity's Mossbauer spectrometer. Science 306:1740-1745.
Kminek, G., and Bada, J.L. (2006) The effect of ionizing radiation on the preservation of amino acids on Mars. Earth Planet Sci Lett 245, doi:10.1016/j.epsl.2006.03.008.

Kohnen, M.E.L., Damsté, J.S.S., ten Haven, H.L., and de Leeuw, J.W. (1989) Early incorporation of polysulphides in sedimentary organic matter. Nature 341:640-641.

Koopmans, M.P., De Leeuw, J.W., Lewan, M.D., and Sinninghe Damste, J.S. (1996) Impact of dia- and catagenesis on sulphur and oxygen sequestration of biomarkers as revealed by artificial maturation of an immature sedimentary rock. Org Geochem 25:391-426.

Kounaves, S.P., Hecht, M.H., West, S.J., Morookian, J.M., Young, S.M.M., Quinn, R., Grunthaner, P., Wen, X., Weilert, M., Cable, C.A., Fisher, A., Gospodinova, K., Kapit, J., Stroble, S., Hsu, P.C., Clark, B.C., Ming, D.W., and Smith, P.H. (2009) The MECA wet chemistry laboratory on the 2007 Phoenix Mars Scout lander. J Geophys Res Planets 114, doi: 10.1029/2008JE003084.

Lalonde, K., Mucci, A., Ouellet, A., and Gelinas, Y. (2012) Preservation of organic matter in sediments promoted by iron. Nature 483:198-200.

Lewan, M.D. (1985) Evaluation of petroleum generation by hydrous pyrolysis experimentation. Philos Trans A Math Phys Eng Sci 315:123-134.

Lewis, J.M.T., Najorka, J., Watson, J.S., and Sephton, M.A. (2018) The search for Hesperian organic matter on Mars: pyrolysis studies of sediments rich in sulfur and iron. Astrobiology 18:454-464.

Lewis, J.M.T., Watson, J.S., Najorka, J., Luong, D., and Sephton, M.A. (2015) Sulfate minerals: a problem for the detection of organic compounds on Mars? Astrobiology 15:247-258.

Mahaffy, P.R., Webster, C.R., Cabane, M., Conrad, P.G., Coll, P., Atreya, S.K., Arvey, R., Barciniak, M., Benna, M., Bleacher, L., Brinckerhoff, W.B., Eigenbrode, J.L., Carignan, D., Cascia, M., Chalmers, R.A., Dworkin, J.P., Errigo, T., Everson, P., Franz, H., Farley, R., Feng, S., Frazier, G., Freissinet, C., Glavin, D.P., Harpold, D.N., Hawk, D., Holmes, V., Johnson, C.S., Jones, A., Jordan, P., Kellogg, J., Lewis, J., Lyness, E., Malespin, C.A., Martin, D.K., Maurer, J., McAdam, A.C., McLennan, D., Nolan, T.J., Noriega, M., Pavlov, A.A., Prats, B., Raaen, E., Sheinman, O., Sheppard, D., Smith, J., Stern, J.C., Tan, F., Trainer, M., Ming, D.W., Morris, R.V., Jones, J., Gundersen, C., Steele, A., Wray, J., Botta, O., Leshin, L.A., Owen, T., Battel, S., Jakosky, B.M., Manning, H., Squyres, S., Navarro-González, R., McKay, C.P., Raulin, F., Sternberg, R., Buch, A., Sorensen, P., KlineSchoder, R., Coscia, D., Szopa, C., Teinturier, S., Baffes, C., Feldman, J., Flesch, G., Forouhar, S., Garcia, R., Keymeulen, D., Woodward, S., Block, B.P., Arnett, K., Miller, R., Edmonson, C., Gorevan, S., and Mumm, E. (2012) The Sample Analysis at Mars investigation and instrument suite. Space Sci Rev 170:401-478.

Matthewman, R., Martins, Z., and Sephton, M. (2013) Type IV kerogens as analogues for organic macromolecular materials in aqueously altered carbonaceous chondrites. Astrobiology 13:324-33.

Mayer, L.M. (1994) Relationships between mineral surfaces and organic carbon concentrations in soils and sediments. Chem Geol 114:347-363.

Meyers, P.A., and Quinn, J.G. (1971) Fatty acid-clay mineral association in artificial and natural sea water solutions. Geochim Cosmochim Acta 35:628-632.

Milliken, R.E., Grotzinger, J.P., and Thomson, B.J. (2010) Paleoclimate of Mars as captured by the stratigraphic record in Gale Crater. Geophys Res Lett 37, doi:10.1029/2009GL041870. 
Ming, D.W., Lauer, H.V, Archer, P.D., Sutter, B., Golden, D.C., Morris, R.V., Niles, P.B., and Boynton, W.V. (2009) Combustion of organic molecules by the thermal decomposition of perchlorate salts: implications for organics at the Mars Phoenix Scout Landing site [abstract 2241]. In 40th Lunar and Planetary Science Conference, Lunar and Planetary Institute, Houston.

Mißbach, H., Duda, J.P., Lünsdorf, N.K., Schmidt, B.C., and Thiel, V. (2016) Testing the preservation of biomarkers during experimental maturation of an immature kerogen. Int $J$ Astrobiol 15:165-175.

Mißbach, H., Steininger, H., Thiel, V., and Goetz, W. (2019) Investigating the effect of perchlorate on flight-like gas chromatography-mass spectrometry as performed by MOMA on board the ExoMars 2020 rover. Astrobiology 19:1339-1352.

Moldoveanu, S.C. (2010a) Pyrolysis of Organic Molecules with Applications to Health and Environmental Issues, Techniques and Instrumentation in Analytical Chemsitry Vol. 28, Elsevier, Amsterdam.

Moldoveanu, S.C. (2010b. Pyrolysis of carbohydrates. In Techniques and Instrumentation in Analytical Chemistry, Elsevier, Amsterdam, pp 419-470.

Montgomery, W., Jaramillo, E.A., Royle, S.H., Kounaves, S.P., Schulze-Makuch, D., and Sephton, M.A. (2019) Effects of oxygen-containing salts on the detection of organic biomarkers on Mars and in terrestrial analog soils. Astrobiology 19:711-721.

Mustard, J., Adler, M., Allwood, A., Bass, D., Beaty, D., Bell, J., Brinckerhoff, W., Carr, M., Des Marais, D., Drake, B., Edgett, K., Grant, J., Milkovich, S., Ming, D., Murchie, S., Onstott, T., Ruff, S., Sephton, M., Steele, A., and Treiman, A. (2013) Report of the Mars 2020 Science Definition Team, posted July 2013 by the Mars Exploration Program Analysis Group (MEPAG). Available online at http://mepag.jpl.nasa.gov/ reports/MEP/Mars_2020_SDT_Report_Final.pdf

Ourisson, G., and Albrecht, P. (1992) Hopanoids. 1. Geohopanoids: the most abundant natural products on Earth? Acc Chem Res 25:398-402.

Papike, J.J., Karner, J.M., and Shearer, C.K. (2006) Comparative planetary mineralogy: implications of martian and terrestrial jarosite. a crystal chemical perspective. Geochim Cosmochim Acta 70:1309-1321.

Parenteau, M.N., and Cady, S.L. (2010) Microbial biosignatures in iron-mineralized phototrophic mats at Chocolate Pots Hot Springs, Yellowstone National Park, United States. Palaios 25:97-111.

Pavlov, A.A., Vasilyev, G., Ostryakov, V.M., Pavlov, A.K., and Mahaffy, P. (2012) Degradation of the organic molecules in the shallow subsurface of Mars due to irradiation by cosmic rays. Geophys Res Lett 39:5-9.

Peters, K.E., Moldowan, J.M., and Sundararaman, P. (1990) Effects of hydrous pyrolysis on biomarker thermal maturity parameters: Monterey phosphatic and siliceous members. Org Geochem 15:249-265.

Peters, K.E., Walters, C.C., and Moldowan, J.M. (2005) The Biomarker Guide: Volume 1. Biomarkers and Isotopes in the Environment and Human History, Cambridge University Pres, Cambridge, UK.

Preston, L.J., Shuster, J., Fernández-Remolar, D., Banerjee, N.R., Osinski, G.R., and Southam, G. (2011) The preservation and degradation of filamentous bacteria and biomolecules within iron oxide deposits at Río Tinto, Spain. Geobiology 9:233-249.

Rampe, E.B., Ming, D.W., Blake, D.F., Bristow, T.F., Chipera, S.J., Grotzinger, J.P., Morris, R.V., Morrison, S.M., Vaniman,
D.T., Yen, A.S., Achilles, C.N., Craig, P.I., Des Marais, D.J., Downs, R.T., Farmer, J.D., Fendrich, K.V., Gellert, R., Hazen, R.M., Kah, L.C., Morookian, J.M., Peretyazhko, T.S., Sarrazin, P., Treiman, A.H., Berger, J.A., Eigenbrode, J., Fairén, A.G., Forni, O., Gupta, S., Hurowitz, J.A., Lanza, N.L., Schmidt, M.E., Siebach, K., Sutter, B., and Thompson, L.M. (2017) Mineralogy of an ancient lacustrine mudstone succession from the Murray Formation, Gale Crater, Mars. Earth Planet Sci Lett 471:172-185.

Reeves, J.B., and Francis, B.A. (1998) Pyrolysis-gas chromatography for the analysis of proteins: with emphasis on forages. In Nitrogen-Containing Macromolecules in the Bioand Geosphere, ACS Symposium Series Vol. 707, edited by B.A. Stankiewicz and P.F. van Bergen, American Chemical Society, Washington, DC, pp 47-62.

Rohmer, M., Bouvier, P., and Ourisson, G. (1979) Molecular evolution of biomembranes: structural equivalents and phylogenetic precursors of sterols. Proc Natl Acad Sci USA 76: 847-851.

Rohmer, M., Bouvier-Nave, P., and Ourisson, G. (1984) Distribution of hopanoid triterpenes in prokaryotes. Microbiology 130:1137-1150.

Royle, S.H., Oberlin, E., Watson, J.S., Montgomery, W., Kounaves, S.P., and Sephton, M.A. (2018a) Perchloratedriven combustion of organic matter during pyrolysis-gas chromatography-mass spectrometry: implications for organic matter detection on Earth and Mars. J Geophys Res Planets 123:1901-1909.

Royle, S.H., Tan, J., Kounaves, S.P., and Sephton, M.A. (2018b) Survivability of 1-chloronapthalene during simulated early diagenesis: implications for chlorinated hydrocarbon detection on Mars. J Geophys Res Planets 123:2790-2802.

Saiz-Jimenez, C. (1994) Production of alkylbenzenes and alkylnaphthalenes upon pyrolysis of unsaturated fatty acids. Naturwissenschaften 81:451-453.

Saiz-Jimenez, C. (1995) The origin of alkylbenzenes and thiophenes in pyrolysates of geochemical samples. Org Geochem 23:81-85.

Saiz-Jimenez, C., and de Leeuw, J.W. (1984) Pyrolysis-gas chromatography-mass spectrometry of isolated, synthetic and degraded lignins. Org Geochem 6:417-422.

Sephton, M.A., and Botta, O. (2005) Recognizing life in the Solar System: guidance from meteoritic organic matter. Int $J$ Astrobiol 4:269-276.

Sephton, M.A., Lewis, J.M.T., Watson, J.S., Montgomery, W., and Garnier, C. (2014) Perchlorate-induced combustion of organic matter with variable molecular weights: implications for Mars missions. Geophys Res Lett 41:7453-7460.

Severson, R.F., Schuller, W.H., and Lawernce, R.V. (1972) Pyrolyses of certain resin acids at $800^{\circ}$. J Chem Eng Data 17: 250-252.

Shimoyama, A., and Johns, W.D. (1971) Catalytic conversion of fatty acids to petroleum-like paraffins and their maturation. Nat Phys Sci 232:140-144.

Shuai, W., Gu, C., Fang, G., Zhou, D., and Gao, J. (2019) Effects of iron (hydr)oxides on the degradation of diethyl phthalate ester in heterogeneous (photo)-Fenton reactions. J Environ Sci (China) 80:5-13.

Sidhu, P.S., Gilkes, R.J., Cornell, R.M., Posner, A.M., and Quirk, J.P. (1981) Dissolution of iron oxides and oxyhydroxides in hydrochloric and perchloric acids. Clays Clay Miner 29:269-276.

Sinninghe Damste, J.S., and De Leeuw, J.W. (1990) Analysis, structure and geochemical significance of organically bound 
sulphur in the geosphere: state of the art and future research. Org Geochem 16:1077-1101.

Sinninghe Damste, J.S., Rijpstra, W.I.C., Kock-van Dalen, A.C., De Leeuw, J.W., and Schenck, P.A. (1989) Quenching of labile functionalised lipids by inorganic sulphur species: evidence for the formation of sedimentary organic sulphur compounds at the early stages of diagenesis. Geochim Cosmochim Acta 53:1343-1355.

Squyres, S.W., Grotzinger, J.P., Arvidson, R.E., Bell, J.F., III, Calvin, W., Christensen, P.R., Clark, B.C., Crisp, J.A., Farrand, W.H., Herkenkoff, K.E., Johnson, J.R., Klingelhöfer, G., Knoll, A.H., McLennan, S.M., McSween, H.Y., Jr., Morris, R.V., Rice, J.W., Jr., Rieder, R., and Soderblom, L.A. (2004) In situ evidence for an ancient aqueous environment at Meridiani Planum, Mars. Science 306:1709-1714.

Sutter, B., McAdam, A.C., Mahaffy, P.R., Ming, D.W., Edgett, K.S., Rampe, E.B., Eigenbrode, J.L., Franz, H.B., Freissinet, C., Grotzinger, J.P., Steele, A., House, C.H., Archer, P.D., Malespin, C.A., Navarro-González, R., Stern, J.C., Bell, J.F., Calef, F.J., Gellert, R., Glavin, D.P., Thompson, L.M., and Yen, A.S. (2017) Evolved gas analyses of sedimentary rocks and eolian sediment in Gale Crater, Mars: results of the Curiosity rover's Sample Analysis at Mars instrument from Yellowknife Bay to the Namib Dune. J Geophys Res Planets 122:2574-2609.

Tan, J., Lewis, J.M.T., and Sephton, M.A. (2018) The fate of lipid biosignatures in a Mars-analogue sulfur stream. Sci Rep 8, doi:10.1038/s41598-018-25752-7.

Tan, J., Sephton, M.A. (2019) Organic records of Early Life on Mars: The Role of Iron, Burial and Kinetics on Preservation. Astrobiology 20:52-72. doi:10.1089/ast.2019.2046.

Tegelaar, E.W., de Leeuw, J.W., Derenne, S., and Largeau, C. (1989) A reappraisal of kerogen formation. Geochim Cosmochim Acta 53:3103-3106.

Tissot, B.P., and Welte, D.H. (1984) From kerogen to petroleum. In Petroleum Formation and Occurrence, Springer, Berlin, pp 160-198.

Traitler, H., and Kratzl, K. (1980) On the formation of degradation products from the pyrolysis of tall oil fatty acids with kraft lignin. J Am Oil Chem Soc 57:153-156.

van Der Kaaden, A., Haverkamp, J., Boon, J.J., and De Leeuw, J.W. (1983) Analytical pyrolysis of carbohydrates. J Anal Appl Pyrolysis 5:199-220.

Versteegh, G.J.M., Blokker, P., Wood, G.D., Collinson, M.E., Sinninghe Damsté, J.S., and De Leeuw, J.W. (2004) An example of oxidative polymerization of unsaturated fatty acids as a preservation pathway for dinoflagellate organic matter. Org Geochem 35:1129-1139.

Vestal, J.R., and White, D.C. (1989) Lipid analysis in microbial ecology: quantitative approaches to the study of microbial communities. Bioscience 39:535-541.

Volkman, J.K., Barrett, S.M., Blackburn, S.I., Mansour, M.P., Sikes, E.L., and Gelin, F. (1998) Microalgal biomarkers: a review of recent research developments. Org Geochem 29:1163-1179.

Watson, J.S., and Sephton, M.A. (2015) Heat, aromatic units, and iron-rich phyllosilicates: a mechanism for making macromolecules in the early Solar System. Astrobiology 15:787792.

Westall, F., Foucher, F., Bost, N., Bertrand, M., Loizeau, D., Vago, J.L., Kminek, G., Gaboyer, F., Campbell, K.A., Bréhéret, J.-G., Gautret, P., and Cockell, C.S. (2015) Biosignatures on Mars: what, where, and how? Implications for the search for martian life. Astrobiology 15:998-1029.
White, D.C. (1993) In situ measurement of micorbial biomass, community structure and nutritional status. Philos Trans $R$ Soc B Biol Sci 344:59-67.

Williams, A.J., Sumner, D.Y., Alpers, C.N., Karunatillake, S., and Hofmann, B.A. (2015) Preserved filamentous microbial biosignatures in the Brick Flat Gossan, Iron Mountain, California. Astrobiology 15:637-668.

Williams, A.J., Eigenbrode, J.L., Wilhelm, M.B., Cook, C., and Mahaffy, P.R. (2016) Physical and molecular biosignature preservation in hydrous ferric oxides: implications for detection on Mars with MSL and future missions [abstract]. In Biosignature Preservation and Detection in Mars Analog Environments, Lunar and Planetary Institute, Houston.

Williams, A.J., Eigenbrode, J., Floyd, M., Wilhelm, M.B., O'Reilly, S., Johnson, S.S., Craft, K.L., Knudson, C.A., Andrejkovičová, S., Lewis, J.M.T., Buch, A., Glavin, D.P., Freissinet, C., Williams, R.H., Szopa, C., Millan, M., Summons, R.E., McAdam, A., Benison, K., Navarro-González, R., Malespin, C., and Mahaffy, P.R. (2019) Recovery of fatty acids from mineralogic Mars analogs by TMAH thermochemolysis for the Sample Analysis at Mars Wet Chemistry Experiment on the Curiosity rover. Astrobiology 19:522-546.

Wood, M.H., Casford, M.T., Steitz, R., Zarbakhsh, A., Welbourn, R.J.L., and Clarke, S.M. (2016) Comparative adsorption of saturated and unsaturated fatty acids at the iron oxide/ oil interface. Langmuir 32:534-540.

Zafar, R., and Watson, J.S. (2017) Adsorption of tetradecanoic acid on kaolinite minerals: using flash pyrolysis to characterise the catalytic efficiency of clay mineral adsorbed fatty acids. Chem Geol 471:111-118.

Address correspondence to: Jonathan Tan Impacts and Astromaterials Research Centre Department of Earth Science and Engineering Imperial College London SW7 2AZ London

$U K$

E-mail: jonathan.tan12@imperial.ac.uk

Submitted 17 December 2019

Accepted 29 September 2020 Associate Editor: Russell Shapiro

$\begin{aligned} & \text { Abbreviations Used } \\ \mathrm{CP} & =\text { samples from the clay-poor stream } \\ \mathrm{CR} & =\text { samples from the clay-rich stream } \\ \mathrm{DCM} & =\text { dichloromethane } \\ \mathrm{DI} & =\text { deionized } \\ \mathrm{GC} & =\text { gas chromatograph } \\ \mathrm{MOMA} & =\text { Mars Organic Molecule Analyzer } \\ \mathrm{MS} & =\text { mass spectrometer } \\ \mathrm{PAHs} & =\text { polyaromatic hydrocarbons } \\ \text { py-GC-MS } & =\text { pyrolysis-gas chromatography-mass } \\ \mathrm{GAM} & \text { spectrometry } \\ \mathrm{SAM} & =\text { Sample Analysis at Mars } \\ \mathrm{TIC} & =\text { total ion current } \\ \mathrm{XRD} & =\text { X-ray diffraction }\end{aligned}$

